\title{
Classification and mapping of anthropogenic landforms on cultivated hillslopes using DEMs and soil thickness data - Example from the SW Parisian Basin, France
}

\author{
C. Chartin' ${ }^{\mathrm{a}}$, H. Bourennane ${ }^{\underline{b}}$, S. Salvador-Blanes ${ }^{\mathrm{a}}$, F. Hinschberger ${ }^{\mathrm{a}}$, J.-J. Macaire ${ }^{\underline{a}}$
}

Université François-Rabelais de Tours, Université d'Orléans, CNRS/INSU, Institut des

${ }^{a}$ Sciences de la Terre d'Orléans, UMR 6113, Faculté des Sciences et Techniques, Parc Grandmont, 37200 Tours, France

b INRA - Unité de Science du Sol, 2163 avenue de la Pomme de Pin, CS 40001 Ardon, 45075 Orléans Cedex 2, France

\begin{abstract}
This study focuses on linear anthropogenic landforms of decametric width on cultivated hillslopes and their relations to soil thickness variability. The 16 ha study area shows a rolling topography supported by Cretaceous chalk of the SW Parisian Basin, France. Two types of landforms were identified: lynchets, similar to those described as soil terraces occurring on downslope field parts in other contexts, and undulations, linear, convex landforms that cut across fields. Accurate DEM construction and a detailed soil thickness survey were performed all over the study area. Soil samples were classified considering their location on specific types of anthropogenic landforms. The Classification Tree (CT) method was applied to assess whether lynchets and undulations can be discriminated through morphometric attributes (slope, curvature, profile curvature and planform curvature) and soil thickness $\left(\mathrm{CT}_{\text {soil }}\right)$ or through morphometric attributes only $\left(\mathrm{CT}_{\text {topo }}\right)$. The $\mathrm{CT}$ application establishes predictive classification models to map the spatial distribution of lynchets and undulations over the whole study area. The validation results of the $\mathrm{CT}_{\text {soil }}$ and $\mathrm{CT}_{\text {topo }}$ applications show model efficiencies of $83 \%$ and $67 \%$, respectively. Both models performed well for lynchets. Errors arise mainly from difficulties in unequivocally discriminating gently convex undulations and undifferentiated surfaces, especially when soil thickness is not accounted for. Mean values of soil thickness are 1.08, 0.62 and $0.45 \mathrm{~m}$ in lynchets, undulations and undifferentiated areas, respectively. The general shape of the thickened soil is characteristic to each type of anthropogenic landform. Multi-temporal mapping of field border networks shows that undulations are linked to borders that were removed during the latest land consolidation. Lynchets are associated with current field borders. Lynchets and undulations, which cover $39 \%$ of the study area, define topographic indicators of human-induced soil accumulations. The method involves perspectives for efficiently mapping and quantifying the anthropogenically modified spatial variability of soil thickness on agricultural hillsides.
\end{abstract}

\section{Introduction}

The thickness and horizonation of soil cover result from the interaction of soil forming processes through parent-rock weathering and erosion or accumulation of matter at the soil surface (e.g., [Jenny, 1941] and [Huggett, 1997] ). Accordingly, the thicknesses of the A and B horizons, as well as solum thickness are important diagnostic features for soil classification schemes (e.g., FAO, 1998). Moreover, soil properties such as water storage capacity and carbon content are sensitive to thickness variations ( [Van Wesemael et al., 2000], [Yoo et 
al., 2006] and [Follain et al., 2007] ). Soil thickness variation has a direct impact on crop quality and yields on cultivated land ( [Power et al., 1981] , [Christensen and McElyea, 1988] and [Kosmas et al., 2001] ). Recording soil thickness in agrarian landscapes, therefore, appears to be important for soil mapping.

Soil thickness is strongly linked to landscape morphology. Slope gradient is a major factor for soil development because it affects soil stability against gravity-induced movements (soil creep, landslide and debris flows) and controls rill and interrill erosion ( [Gerrard, 1981] , [Vandaele et al., 1996] and [Chaplot and Le Bissonnais, 2000] ). The notion of landscape is predominated by the assumption of spatial heterogeneity that includes patterning or structuration ( [Turner et al., 2001] , [Farina, 2006] and [Bolliger et al., 2007] ). Meeus et al. (1990) defined agricultural landscapes as areas where "management is manifest and the interaction of such factors as soil conditions, elevation, use, management and history are visible in the landscape and are expressed in its form and layout". Few contiguous fields or several hundred hectares dedicated to agricultural practices can define an agricultural landscape. Landscape morphology primarily depends on natural parameters: tectonics, lithology and climate (Derruau, 1962). In addition to natural factors, human activities can significantly affect geomorphology. Anthropogenic deforestation often induces a significant increase in soil erosion ( [De Moor et al., 2008] and [Macaire et al., 2010] ). Landscape fragmentation by field border networks has also important effects on the spatial variability of soil erosion ( [Van Oost et al., 2000] , [Follain et al., 2006] and [Szilassi et al., 2006] ). The spatial variability of tillage erosion is affected by field geometry as soil translocation by tillage implements occurs exclusively within field limits. Field borders act then as barriers to soil matter fluxes for tillage translocation, and also to fluxes for water translocation when borders are vegetalised ( [Dabney et al., 1999] , [Govers et al., 1999] , [De Alba, 2003] , [Van Dijk et al., 2005] and [Knapen et al., 2008] ). This leads to the formation of anthropogenic landforms that relate to local soil erosion/accumulation such as ridges-and-furrows, headlands, and lynchets that are frequently found in Western Europe (Callot, 1980, [Hooke, 1988] , [Zadora-Rio, 1991] and [Houben, 2008] ). These features can be unintentional or intentional, when they are used for soil and water conservation systems (ridges-and-furrows and lynchets) or as biodiversity conservation systems (headlands) ( [Taylor, 1975] , [Corbet, 1995] and Bellemlih, 1999).

In soil science and geomorphology, lynchets provide an example of an anthropogenic landform resulting from agricultural practices. Lynchets are also known as terraces, soil banks or fence lines. They are locally called "rideaux" in northern France and Belgium. A lynchet is predominantly shaped by the progressive accumulation of soil material by water and/or tillage translocation upslope of a field border ( [Bollinne, 1971] , [Papendick and Miller, 1977] , [Van Dijk et al., 2005] and [Follain et al., 2007] ). This leads to the creation of a gentler slope than in the upslope field area and an associated break-in-slope below the field border. Depending on the slope gradient upslope and the degree of development of the lynchet, the break-in-slope can range from several decimetres to a few meters height ( [Papendick and Miller, 1977] and [Salvador-Blanes et al., 2006] ). Moreover, the benching effect tends to be amplified by erosion downslope of the break-in-slope ( [Van Oost et al., 2000] and [Follain et al., 2007] ). Although lynchets are of decametric width, they may store an important proportion of soil material on cultivated hillslopes because of their frequent occurrence in the landscape (Macaire et al., 2002).

Previously cited studies suppose that the lynchets could reflect different degrees of development and quantities of accumulated soil material depending on their morphometric 
attributes. Whereas relief was demonstrated as a useful and dominant predictive variable on the spatial distribution of soils and associated thicknesses (e.g., [Huggett, 1975] , Bourennane, 1997, [Heimsath et al., 1999] and [King et al., 1999] ), few studies linked mathematically the morphologies of the anthropogenic features to their associated soil thicknesses. The easy acquisition of elevation data for large-scale areas makes its use very common for soil mapping ( [Odeh et al., 1994] , [Gessler et al., 1995] , [Isambert et al., 1997] and [Grinand et al., 2008] ).

The objective of this paper is to assess whether different types of anthropogenic landforms can be discriminated by their morphometric attributes and soil thicknesses. We proceeded to obtain accurate elevation records and conducted a detailed soil thickness survey with two different sampling strategies on anthropogenic landforms and undifferentiated surfaces. We developed a method to classify soil samples considering their location on or outside of specific types of anthropogenic landforms. We then executed predictive modelling of the belonging of a sample to the different types of anthropogenic landforms or surrounding undifferentiated surfaces using Classification Tree (CT) analysis (Breiman et al., 1984). Results were analysed to assess the statistical relevance of morphological and soil thickness differences between types of anthropogenic landforms and with undifferentiated surfaces. Finally, we examined the influence of landscape fragmentation on the anthropogenic landforms and the convenience of using this method for soil quantification and mapping.

\section{Materials and methods}

\subsection{Study area}

\subsubsection{Location and physiographical settings}

The field study was carried out on a 16 ha southeast-facing hillslope located near the village of Seuilly within the Quincampoix catchment (southwestern Parisian Basin, $47^{\circ} 08.31^{\prime} \mathrm{N}$, $0^{\circ} 10.97^{\prime} \mathrm{E}$; Fig. 1). The elevation of the study area ranges from 37 to $80 \mathrm{~m}$, and the slope length is approximately $750 \mathrm{~m}$. This hillslope has a rolling topography that is representative of the Upper Cretaceous formations of the southwestern Parisian Basin bedrocks. The studied hillslope is composed of the following sedimentary bedrocks from thalweg to crest: Upper Cenomanian sandy marl, Lower and Middle Turonian white chalks, and Upper Turonian yellow sandy limestones (Alcaydé et al., 1989 and Bellemlih, 1999). The main soils observed in this area are calcaric Cambisols, epileptic calcaric Cambisols and colluvic Cambisols (Boutin et al., 1990, [FAO, 1998] and Bellemlih, 1999).

Modern land-use consists of cultivated cereals and oil-producing crops (maize, wheat, barley, sunflower and rape). Vineyards, orchards and pastures covered over 30\% of the study area until the beginning of the last century. The field border network has evolved remarkably since 1836 but has not changed since the last important land consolidation occurred at the end of the 1960s (Fig. 2).

\subsubsection{Characteristics of the anthropogenic landforms in the study area}

Lynchets and undulations are two types of linear anthropogenic landforms that have been identified in the study area. Their axes are predominantly oriented at right angles to the main slope direction. 
Fig. 3a,c show the geometrical characteristics of a typical lynchet. It is characterised by two morphological components separated from one another by a field border, i.e., its axis. The first morphological component corresponds to a gentle slope extending a few decametres upslope of the axis. This gentle slope becomes gradually higher to connect to the upslope field area and tends to become close to zero when reaching the field border downslope. The second component is a few-meters wide break-in-slope located downslope of the axis. Breaks-inslope can locally be more than $2 \mathrm{~m}$ high and create sharp discontinuities in the studied hillslope. Some augerings were carried out in the study area during a previous study (Bellemlih, 1999). These augerings show soil thickening in the lynchets: soil thicknesses ranged from 75 to $130 \mathrm{~cm}$ in lynchets compared to $40 \mathrm{~cm}$ to $>1 \mathrm{~m}$ in surrounding areas.

\subsubsection{Characteristics of the anthropogenic landforms in the study area}

Lynchets and undulations are two types of linear anthropogenic landforms that have been identified in the study area. Their axes are predominantly oriented at right angles to the main slope direction.

Fig. 3a,c show the geometrical characteristics of a typical lynchet. It is characterised by two morphological components separated from one another by a field border, i.e., its axis. The first morphological component corresponds to a gentle slope extending a few decametres upslope of the axis. This gentle slope becomes gradually higher to connect to the upslope field area and tends to become close to zero when reaching the field border downslope. The second component is a few-meters wide break-in-slope located downslope of the axis. Breaks-inslope can locally be more than $2 \mathrm{~m}$ high and create sharp discontinuities in the studied hillslope. Some augerings were carried out in the study area during a previous study (Bellemlih, 1999). These augerings show soil thickening in the lynchets: soil thicknesses ranged from 75 to $130 \mathrm{~cm}$ in lynchets compared to $40 \mathrm{~cm}$ to $>1 \mathrm{~m}$ in surrounding areas.

\subsection{Data acquisition}

\subsubsection{Topography}

Two DGPS (Trimble ${ }^{\circledR}$ ProXRS) were used as a base and a mobile recorder, respectively. Coordinates (accuracy in $x$ and $y$ : a few millimetres) and elevations (accuracy in $z$ : approximately one centimetre) of 1550 points were obtained by data post-treatment. Four digital elevation models (DEMs) were produced independently on a 2-m grid, i.e., one DEM for each area delineated by lynchet breaks-in-slope (noted 1 to 4 in Fig. 1). The partitioning of the dataset into four subsets was added to the mapping procedure to avoid levelling of the lynchets when computing the DEMs. This virtual levelling would indeed imply a weak predictive power of the morphometric attributes derived from the DEMs. Finally, slope, profile curvature, planform curvature and curvature were derived from each DEM. The curvature was calculated using an algorithm developed by Zevenbergen and Thorne (1987).

\subsubsection{Soil thickness}

Soil thickness was measured by manual augering and defined as the summation of A and B horizons, i.e., the depth of the upper saprolite limit. Differentiation between B and C horizons was relatively easy because $\mathrm{C}$ horizons are white and the transition is sharp. As proposed by Follain et al. (2006), two sampling schemes were established to consider short-distance variability of soil thickness, especially the variability associated with linear anthropogenic 
landforms ( [Bollinne, 1971] , [Macaire et al., 2002] and [Salvador-Blanes et al., 2006] ). The two sampling schemes were defined as follows:Sampling $\Sigma 502$ soil augerings were carried out on the nine most relevant linear landforms observed in the study area, i.e., three lynchets and six undulations (L1 to L3 and U1 to U6 for lynchets and undulations, respectively; Fig. 4a). The augerings were conducted regularly along transects that were either longitudinal or perpendicular to the landform axes (Fig. 4a). Longitudinal transects correspond to landform axes where one augering was performed every $8 \mathrm{~m}$ (Fig. 4b). A perpendicular transect crosses each longitudinal transect every $40 \mathrm{~m}$. There is one augering every $4 \mathrm{~m}$ along the perpendicular transects.

Sampling $\Delta 232$ additional soil augerings were performed to precise the variation of soil thickness all over the study area. A point was sampled randomly in each square of a $25 \times 25 \mathrm{~m}$ grid over the whole study area (Fig. 4a).

Both sampling schemes represent a total of 734 points. Twenty percent of the observations (148 points) were randomly selected to constitute the validation set. The remaining $80 \%$ of the dataset (586 points) was used as the calibration set. Then, these 586 points were used to estimate soil thickness over the entire study area using ordinary kriging (e.g., [Goovaerts, 1997] and [Chilès and Delfiner, 1999] ). The estimation of soil thickness, named $\mathrm{STh}_{1}$, was performed over a 2-m regular grid considering the short-distance variation of soil thickness within lynchets and undulations.

\subsection{Expert classification method}

The expert classification method consists of attributing each sampling point to one of the three predefined classes. Class 1 contains all points located on identified lynchets. Class 2 corresponds to points located on identified undulations. Finally, class 0 is "a class by default" that contains points located on undifferentiated surfaces. The expert classification was based on sample location and landform variation in close neighbourhoods. Datasets of sampling $\Sigma$ and sampling $\Delta$ were treated separately.

\subsubsection{Sampling $\Sigma$ classification}

The sampling scheme $\Sigma$ was constructed using longitudinal and perpendicular transects located on the studied linear landforms (Fig. 4). Points sampled along longitudinal transects, i.e., along the landform axes, were automatically classified in class 1 for those located on lynchets and in class 2 for those located on undulations.

Fig. 5 presents an illustration of the expert classification for the perpendicular transects. Areas located downslope of breaks-in-slope were not considered as parts of lynchet landforms. Thus, points sampled downslope of lynchet axes along perpendicular transects were automatically attributed to class 0 (Fig. 5a). For the perpendicular transects located upslope of a lynchet axis and the whole perpendicular transects located on undulations, we defined the points of connection between linear anthropogenic landforms and the surrounding relief (Cf. Section 2.1.2). Then, samples located between the axis of the landform and points of connection were placed in class 1 for lynchets and class 2 for undulations. Points located between connections and transect extremities were placed in class 0 , corresponding to undifferentiated surfaces. 


\subsubsection{Sampling $\Delta$ classification}

Sampling $\Delta$ was dispatched all over the study area (Fig. 4a). For each point close to a lynchet or an undulation, a topographic cross-section perpendicular to the feature axis and crossing the point was extracted from the DEM using ArcGIS 9.3 ®. The classification method was similar to the one applied to points placed along perpendicular transects of sampling scheme $\Sigma$ (Section 2.3.1). All points located on undifferentiated surfaces were attributed to class 0 .

\subsection{Statistical analyses}

\subsubsection{Principle of the Classification Tree (CT) method}

This subsection briefly presents the Classification Tree (CT) method used for the main objective of this study. The convenience of this approach compared to discriminant analysis or logistic regression lies in its non-parametric character (no assumption is required regarding the distribution of the used variables). Several studies have already shown that the CT method is useful for soil attribute prediction and mapping (e.g., Lagacherie, 1992, [Shatar and McBratney, 1999] and [McBratney et al., 2003] ). For a thorough presentation of the CT method, readers should refer to books such as those by [Breiman et al., 1984] and [Steinberg and Colla, 1995] .

A CT corresponds to a model that predicts the class belonging of an object from values of one or more predictor variables (categorical and/or continuous). The tree is built from a calibration dataset; the class belonging and the predictor variables are known for each object of the set. A decision algorithm that partitions into increasingly homogeneous subdatasets is applied to this calibration dataset. At each successive partition, the decision algorithm automatically determines the splitting predictor variables and their values to minimize the variance between the parent dataset and its child subdatasets. When partitioning is achieved, each object from the calibration dataset has been sent to a terminal subdataset assigned to one of the predefined classes (several terminal datasets can be assigned to the same class). Thus, the built tree or 'classification model' consists of a rules-structured classifier. Decision rules follow one another in a fixed order and are based on values of the chosen predictor variables. We applied the Classification And Regression Tree (CART) algorithm developed by Breiman et al. (1984) that generates a binary decision tree. Data are partitioned into a series of descending left and right sub-datasets. This partitioning is recursive; thus, a defined predictor can be used in more than one decision rule.

\subsubsection{Applications of the Classification Tree method}

Here, we first applied the CART algorithm (R Development Core Team, 2010) to the 586point calibration dataset. This set was previously classified into the three predefined classes 0 , 1 and 2 through our expert method (Section 2.3). The predictor variables were the morphometric attributes (slope, curvature, profile curvature and planform curvature) and the soil thickness measured in the field. The resulting tree was called ' $\mathrm{CT}_{\text {soil }}$ '. In order to validate this classification model $\left(\mathrm{CT}_{\text {soil }}\right)$, we proceeded to the mapping of lynchet and undulation landforms all over the study area based on the decision rules of the model. For this purpose, each raster layer corresponding to morphometric attributes and soil thickness $\left(\mathrm{STh}_{1}\right)$ was previously computed over the same regular 2-m grid. Then, we implemented the decision

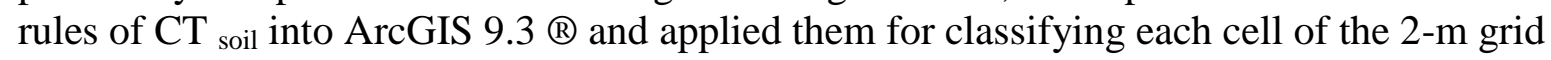
into one of the predefined classes 0,1 or 2 . When values of the predictor variables did not 
correspond to any criteria imposed by $\mathrm{CT}_{\text {soil }}$, the relative cell was automatically classified into class 0 . Once the map was computed, the validation of the $\mathrm{CT}_{\text {soil }}$ model was carried out through the validation dataset. A class was attributed to each point of the validation dataset according to the map and compared with the initial expert classification.

For the purpose of spatial extrapolation beyond areas where soil thickness variable is unavailable, the CART algorithm was tested using only morphometric attributes as predictor variables. This application could constitute a practical tool for the identification and mapping of anthropogenic landforms when soil thickness is unknown or partially known in an area. The resulting classification model was referred to as ' $\mathrm{CT}_{\text {topo }}$ '. The methodology for the validation of the model was similar to the one applied to $\mathrm{CT}_{\text {soil }}$.

\subsection{Quantification of soil material stored in anthropogenic landforms}

We quantified the soil material potentially stored in the anthropogenic landforms revealed by the most efficient classification model amongst $\mathrm{CT}_{\text {soil }}$ and $\mathrm{CT}_{\text {topo }}$. We applied a method substracting the estimation of soil thickness that does not include soil material stored in the anthropogenic landforms $\left(S T h_{2}\right)$ to the estimation of actual soil thickness $\left(S T h_{1}\right)$. We took the following steps for this purpose:

(i) $S T h_{2}$ was computed over the study area using only soil thickness measurements at points belonging to expert class 0 .

(ii) A third raster layer was calculated as follows: $S T h_{\mathrm{st}}=S T h_{1}-S T h_{2}$. It represents the storage soil thickness $t_{i}$ for a given cell of the regular 2-m grid.

(iii) The total volume of soil material stored in each type of landform was calculated separately using Eq. 1

$$
V_{\mathrm{st}}\left(m^{3}\right)=\sum_{i=1}^{n}(t \times e a)
$$

where $i$ is the $i$ th cell for a given landform type, $n$ is the total number of cells of a given landform type, $t_{i}$ is the storage soil thickness for the $i$-th cell given by $S T h_{\mathrm{st}}(\mathrm{m})$, and $e a$ is the cells elementary area (2 $\times 2 \mathrm{~m})$.

\section{Results}

\subsection{Variability of the predictor variables within the study area}

Table 1 summarises statistics of morphometric attributes and measured soil thicknesses for the total 734 sampled points distributed over the entire study area. Slope shows a mean value of $5.3 \%$ with respective minimum and maximum values of $0.16 \%$ and $11.9 \%$. The three different types of curvature present mean values close to null. Curvature presents a wider range of values from -1.00 to $1.18 \mathrm{~m}^{-1}$ when compared to profile and planform curvatures. Ranges of profile and planform curvature values are very distinctive; profile curvature varies from -0.97 to $1.03 \mathrm{~m}^{-1}$, and planform curvature varies from -0.32 to $0.47 \mathrm{~m}^{-1}$. As observed in field, data reflect that the most important short-distance variations of slope gradient are oriented towards the maximum slope direction, perpendicularly to the axes of studied lynchets and undulations (Fig. 6). 
Soil thickness measured in the field ranges from 0.22 to $2.23 \mathrm{~m}$ for the total dataset (Table 1). The mean measured value is $0.62 \mathrm{~m}$ with a standard deviation $(S D)$ of $0.33 \mathrm{~m}$. From the calibration dataset of 586 points, soil thickness was estimated over the entire study area by ordinary kriging. The spatial autocorrelation of soil thickness, quantified through the semivariogram, is quite strong (Fig. 7). A pure nugget $\left(\right.$ sill $=0.01 \mathrm{~m}^{2}$ ) plus a Gaussian model $\left(\right.$ range $=35 \mathrm{~m}$ and sill $\left.=0.05 \mathrm{~m}^{2}\right)$ and a spherical model $\left(\right.$ range $=150 \mathrm{~m}$ and sill $\left.=0.03 \mathrm{~m}^{2}\right)$ were nested to the experimental variogram. A cross validation was used on the original data to validate the variogram models. The mean error is defined as:

$R=\frac{1}{n} \sum_{i=1}^{n}\left[z^{*}\left(x_{i}\right)-z\left(x_{i}\right)\right]$

where $z^{*}\left(x_{\mathrm{i}}\right)$ is the estimated value at $x_{\mathrm{i}}$, and $z\left(x_{\mathrm{i}}\right)$ is the measured value at $x_{\mathrm{i}}$.

$R$ appears close to zero $(-0.00117 \mathrm{~m})$. The ratio of the mean squared error to the kriging variance is:

$S_{R}^{2}=\frac{1}{n} \sum_{i=1}^{n}\left[z^{*}\left(x_{i}\right)-z\left(x_{i}\right)\right]^{2} / \sigma_{\mathrm{k}}^{2}\left(x_{i}\right)$,

where $\sigma^{2}{ }_{\mathrm{k}}\left(x_{i}\right)$ is the theorethical estimation variance for the prediction of $z^{*}\left(x_{i}\right)$.

The ratio is close to unity (1.01628). The short-distance variability of soil thickness appears to be predominantly associated with all the lynchets, L1, L2 and L3, and undulations, especially U2, U4, U5 and U6 (Fig. 8a).

\subsection{Variability of the predictor variables in each expert class}

Table 2 presents summary statistics of morphometric attributes and soil thicknesses for each class and their respective size in the total dataset. The total dataset contains 734 points distributed in the following three classes: class 0 (389 points), class 1 (139 points) and class 2 (206 points). Classes 1 and 2, which are dedicated to the linear landforms of interest, represent $19 \%$ and $28 \%$ of the total dataset, respectively.

According to the summary statistics (Table 2), class 0 presents the largest range of slope values (from $0.84 \%$ to $11.9 \%$ ) and the highest mean slope value (approximately $6 \%$ ). Mean values for each of the three curvatures calculated on undifferentiated surfaces (class 0 ) are null, with an $S D$ value of 0.1 to $0.2 \mathrm{~m}^{-1}$. Class 1 presents the lowest mean slope value $(2.62 \%)$ with a minimum and a maximum of $0.16 \%$ and $9.35 \%$, respectively. Its mean value for planform curvature is null, as observed for classes 0 and 2 . The profile curvature of class 1 appears mainly concave with a mean value of $0.18 \mathrm{~m}^{-1}\left(S D=0.2 \mathrm{~m}^{-1}\right)$. Class 2 shows the highest minimal slope value $(2.37 \%)$ and a mean slope value of $5.73 \%$. The ranges of values for the three curvatures are the lowest in this class. Profile curvature varies from -0.28 to $0.33 \mathrm{~m}^{-1}$.

The lynchets (class 1) present the most important mean measured value of soil thickness (1.08 $\mathrm{m}$ ), and the largest range of soil thickness values (from 0.45 to $2.23 \mathrm{~m}$; Table 2). The soil thickness variability appears higher perpendicularly to lynchets than along their axes. Solum systematically becomes thicker from the upslope to the downslope of a lynchet. A vertical section in this type of landform presents a soil accumulation with an approximated right-angle triangle shape (Fig. 8b). According to Table 2, soil thickness in classes dedicated to 
undifferentiated surfaces and undulations (Classes 0 and 2) does not exceed $1.3 \mathrm{~m}$. Class 2 shows higher minimal and mean soil thickness values than class 0 . Mean values for classes 0 and 2 are 0.45 and $0.62 \mathrm{~m}$, respectively. Soil also presents a particular evolution in undulations. A vertical cross-section in an undulation shows a slight convex lenticular thickening (Fig. 8c).

The Tukey HSD method was applied on the 734-point dataset (Table 3). This statistical test was used to find which ranges of values are significantly different from one another for a given predictor variable. The ranges of values related to classes 0,1 and 2 are statistically different one from another for each of the following predictor variables: soil thickness, profile curvature and curvature. The classes 0 and 2 exhibit similar ranges of values for slope and planform curvature.

\subsection{Classification Tree results}

\subsubsection{The Classification Tree $\mathrm{CT}_{\text {soil }}$}

The overall prediction performance of the CT method is more than $80 \%$ when applied to morphometric attributes and soil thickness values of the pre-classified calibration dataset (Table 4). The confusion matrix shows that the resulting regression tree $\mathrm{CT}_{\text {soil }}$ performs well for classes 0 and 1 . Classes 0 and 1 have $87.5 \%$ and $85.0 \%$ of their respective points correctly classified. Approximately three-fourth of the misclassified points from class 0 are classified in class 2 . Concerning class 1 , the main errors of the model appear to involve class 0 . In class 2 , $24.0 \%$ of points are incorrectly classified; they are all allocated to class 0 by the model. The most important risk of confusion during the application of the $\mathrm{CT}_{\text {soil }}$ model then involves classes 0 and 2 .

Table 5 presents validation results for the $\mathrm{CT}_{\text {soil }}$ model performed through the validation dataset and the mapping of lynchets and undulations over the study area based on the decision rules of the concerned model (Fig. 9a). According to the validation procedure, $83.1 \%$ of the points from the validation dataset are correctly classified. Classes 0,1 and 2 have $80.0 \%, 92.3 \%$ and $79.5 \%$ of their points correctly classified, respectively. The classification model $\mathrm{CT}_{\text {soil }}$ appears significantly relevant. Among points misclassified from the original class 0 , confusions with classes 1 and 2 are almost equivalent. Six points are allocated to class 1 , and eight points are allocated to class 2 . Concerning class 2 (undulations), three-fourths of the misclassified points are confused with class 0 by the $\mathrm{CT}_{\text {soil }}$ model. Confusion between classes 0 and 2 appears to be the most important. This confusion explains why these classes present less efficient classification results than class 1 .

The mapping of the studied landforms based on the decision rules of $\mathrm{CT}_{\text {soil }}$ is shown in Fig. 9a. The three lynchets, L1, L2 and L3 (class 1), and five of the six sampled undulations, U1, U2, U4, U5 and U6 (class 2), are detected and mapped using the $\mathrm{CT}_{\text {soil }}$ model. Unfortunately, some cells located in U3 are mapped as belonging to either class 1 or 0 . A fourth linear lynchet landform, L4, is detected along the downslope site border. Three pseudolinear areas (L5) appear in the northern part of the site. Several linear undulations (U7, U8 and U9) and undulation networks (U10) are identified by the $\mathrm{CT}_{\text {soil }}$ model. Axes of U8 and of some areas of U10 appear oriented along the main slope. Areas mapped in class 1 or 2 that are also not particularly linear and/or of decametric-scale are considered as classification errors. 


\subsubsection{The Classification Tree $\mathrm{CT}_{\text {topo }}$}

$\mathrm{CT}$ analysis on the basis of morphometric attributes was carried out in the outlook of spatial extrapolation beyond areas where the soil thickness variable is unavailable. The CART algorithm applied to the entire 586-point calibration dataset performs weakly when the soil thickness predictor variable is ignored (results not shown). This is mainly due to difficulties discriminating class 2 from class 0 . However, the CART algorithm applied to the subset of the calibration dataset including only classes 1 and 2 (267 points from the total of 586 of the calibration dataset) performs better. The confusion matrix (Table 6) reveals that the individuals of each class are well classified. The overall performance is more than $96 \%$. Only one point of 167 points from class 2 is allocated to class 1 by the $\mathrm{CT}_{\text {topo }}$ model, and eight of the 100 points from class 1 are allocated to class 2 . Classes 1 and 2 can be efficiently discriminated one from another by morphometric attributes only.

Table 7 presents validation results for the $\mathrm{CT}_{\text {topo }}$ model performed through validation dataset and the mapping of lynchets and undulations over the study area based on the decision rules of the concerned model (Fig. 9b). Approximately $67 \%$ of the points from the validation dataset are well reclassified by the $\mathrm{CT}_{\text {topo }}$ model against $83 \%$ for the previous $\mathrm{CT}_{\text {soil }}$ model. A spatial extrapolation beyond the study area where the soil thickness variable is unavailable supposes an overall misclassification of approximately $30 \%$. Regardless of the model used $\left(\mathrm{CT}_{\text {topo }}\right.$ or $\mathrm{CT}_{\text {soil }}$ ), lynchets are well identified in contrast to undulations. According to validation results, about $82 \%$ of points from class 1 and $59 \%$ of points from class 2 are well reclassified. Approximately $38 \%$ of points from class 2 are not recognised by the model as belonging to class 2 , and are then automatically linked to class 0 by default. Nineteen of the 70 points of class 0 have morphometric attributes which correspond to the classification criteria of class 2 defined by the $\mathrm{CT}_{\text {topo }}$ model. Confusion between classes 0 and 2 appears more important when soil thickness is not accounted for.

The mapping of the studied landforms based on the decision rules of $\mathrm{CT}_{\text {topo }}$ shows that lynchets L1, L2 and L3 and undulations U1, U2 and U3 are recognized and mapped (Fig. 9b). Undulations U4 and U5-6 appear partially mapped, and L4, L5, U7, U8, U9 and U10 are detected. The spatial extent of the landforms differs from the $\mathrm{CT}_{\text {soil }}$ results, especially for undulations (class 2). Two additional linear areas are mapped in class 2 (U11 and U12) as well as non-linear areas (U13) located in the northern part of the site.

\subsection{Volume of soil material stored in the anthropogenic landforms}

Table 8 presents results concerning amounts of soil stored in lynchets and undulations. These calculations were made through the application of $\mathrm{CT}_{\text {soil }}$, i.e., the most efficient classification model amongst $\mathrm{CT}_{\text {soil }}$ and $\mathrm{CT}_{\text {topo }}$. According to the mapping of the studied landforms based on $\mathrm{CT}_{\text {soil }}$ decision rules (Fig. 9b), lynchets and undulations cover $14.3 \%$ and $24.3 \%$ of the total study area, respectively. The storage thickness $t_{i}$, defined through the computation of $S T h_{\mathrm{st}}$ (Section 2.5), ranges from 0 to $1.40 \mathrm{~m}$ in lynchets and from 0 to $0.78 \mathrm{~m}$ in undulations. Volumes of soil material stored in these two types of anthropogenic landforms are approximately 6030 and $7520 \mathrm{~m}^{3}$ for lynchets and undulations, respectively. Lynchets and undulations contain then approximately $15 \%$ of the total soil material present in the study area.

\section{Discussion}


The approach presented above aims to identify and distinguish two different types of linear landforms by morphometric attributes and soil thickness. The landforms detailed in the study area appear to be associated with soil thickenings. Therefore, their identification and distinction would allow a better appreciation of soil variability in cultivated hillslopes.

\subsection{Classification efficiency}

The classification method developed here is efficient using morphometric attributes and soil thickness $\left(\mathrm{CT}_{\text {soil }}\right.$ model). Validation results of both classification models $\mathrm{CT}_{\text {soil }}$ and $\mathrm{CT}_{\text {topo }}$ (Table 5 and Table 7, respectively) show that lynchets (class 1) and undulations (class 2) are well discriminated from each other with or without soil thickness. Both models perform well for the recognition of class 1 . However, the undulations are less well identified than lynchets because of confusions between class 2 and class 0 (undifferenciated areas), especially when soil is not accounted for.

Class 1 is the only class that presents significant statistical differences for values of all the predictor variables when compared to the two others classes (Table 3). Lynchets show the highest profile curvature values corresponding to a marked concave shape (Table 2). The mean slope value $(2.6 \%)$ barely reaches half of other class mean values, and its minimum slope is almost null. These statistics seem to reflect the consequent slope gentling associated with lynchet landforms (Fig. 3a,b) and which has been observed in other hilly agricultural regions in western Europe ( [Bracq and Delay, 1997] , Salvador-Blanes, 2002, Follain, 2005, [Houben, 2008] and [Brown, 2009] ). The lynchets studied here present larger soil thickness in comparison to undulations (respectively 1.1 and $0.6 \mathrm{~m}$ in mean thickness against $0.45 \mathrm{~m}$ in undifferentiated surfaces; Table 2). Like relief, soil thickness variability is more accentuated perpendicular to the landform axis than along the axis. Soil thickness increases from upslope to downslope in lynchets (from a few decimetres to more than $1.5 \mathrm{~m}$ ) by the way of a pseudo right-angle triangular accumulation (Fig. 8 b). This shape of soil explains the slope gentling characteristic to lynchet landforms. Lynchets are then easily identified statistically by both the $\mathrm{CT}_{\text {soil }}$ and $\mathrm{CT}_{\text {topo }}$ applications (approximately $92 \%$ and $82 \%$ of performance respectively, Table 5 and Table 7).

The slope and planform curvature modalities of class 2 do not differ statistically from those of class 0 (Table 3 ). Thus, classes 0 and 2 are only distinguishable by curvature and profile curvature in the $\mathrm{CT}_{\text {topo }}$ application. Moreover, profile curvature values range from -0.99 to $0.33 \mathrm{~m}^{-1}$ and from -0.28 to $0.33 \mathrm{~m}^{-1}$ for classes 0 and 2 , respectively (Table 2). The profile curvature does not help to distinguish classes 0 and 2 when its values for the class 0 are close to zero. An undulation is a more discrete and complex feature than a lynchet. Houben (2008) defined undulations as 'horizontal cylindrical segments', and thus highlighted the importance of their median convex areas (Fig. 3c,d). Class 2 statistics do not reflect a dominant convex trend (Table 3). Firstly, this major convex shape is systematically induced by a slight slope gentling upslope (a concavity). Secondly, it often ends also with a second slight concavity downslope. The presence of this second concavity depends on the difference between slope gradient of the undifferentiated areas located upslope and downslope to the undulation. Objects from classes 0 and 2 can then present similar combinations of morphometric attributes. This could explain why the $\mathrm{CT}_{\text {topo }}$ including the three classes did not significantly distinguish classes 0 and 2 .

Soil thickness appears to be an important predictive variable for undulation landforms. We systematically observed a soil thickening in sampling profiles perpendicular to undulations, 
even a slight one $(\sim 10 \mathrm{~cm})$. The thickening shows a convex lenticular shape (Fig. 8c). The mean soil thickness in undulations is $0.62 \mathrm{~m}$ vs. $0.45 \mathrm{~m}$ in undifferentiated areas (Table 2). The intensity of soil thickening in both lynchet and undulation landforms appears to vary along their axes and from one perpendicular sampling transect to another. These shortdistance variations of a few to $>20 \mathrm{~cm}$ seem to have no significant consequences on local relief when compared to the magnitude of relief variation in lynchets and undulations (Fig. 6). The $\mathrm{C}$ horizon upper limit probably presents local irregularities along the different landforms hidden by the shape of overlying thickened soils. In addition, a few subtle undulation landforms (e.g., U5-6) appear associated with important soil thickening; this supports that the $\mathrm{C}$ horizon upper limit is necessarily mostly concave across the landform. In this particular case, the greater soil thickness helps identify undulations (Fig. 9a). Conversely, remarkable undulation landforms (e.g., U3) present slight soil thickening; this supports the idea that the C horizon upper limit is mostly convex across the landform. Consequently, the $\mathrm{CT}_{\text {topo }}$ model does not support the discrimination of classes 0 and 2 (Fig. 9b). These local variations of $\mathrm{C}$ horizon upper limit have a poor effect on the classification efficiency of class 1, considering its very distinctive landform attributes and important soil thicknesses.

\subsection{The imprint of successive field border networks}

Linear lynchet landforms have been described to result from the progressive soil material accumulation upslope of field borders ( [Bollinne, 1971] , [Papendick and Miller, 1977] , [Govers et al., 1999] , Salvador-Blanes, 2002 and [De Alba, 2003] ). Because undulations are linear and associated with thicker soils, they are also possibly related to ancient field borders. Moreover, lynchet and undulation landforms are both predominantly oriented perpendicular to the main slope. Nevertheless, undulation-like landforms can be related to other factors such as a natural increase in soil thickness and/or topographic variation of saprolite upper limit (Section 4.1). Outcropping limits between the underlying chalk and limestone beds appear to be perpendicular to the main slope (Alcaydé et al., 1989). These sedimentary rocks have successive beds of metric-to-decametric-scale and of different compositions, hardnesses. These different rocks are more or less resistant to erosion: their outcroppings could then have influenced local topography and soil profile development. Unfortunately, there is no map of bedrock lithology accurate enough to assess the implication of lithology in the development of undulation landform here. On the contrary, information about historic field system layouts is available. Fig. 10 presents the mapping of lynchets and undulations over the study area performed from $\mathrm{CT}_{\text {soil }}$ model and combined with the field border networks that have been known since 1836. All the linear landforms surveyed in this study are spatially linked to field borders. Lynchets are constructed along present field borders, whereas undulations are located on ancient field borders.

The field borders associated with lynchets L1, L2 and L3 have existed since at least 1836 (Fig. 10). These limits are followed by perennial roads (L1 and L2) or access to the fields (L3), which could have been present for decades to centuries before 1836. A fourth effective lynchet (L4), associated with the field border edging the alluvial plain, has been mapped by CT applications. The field border has existed since at least 1836, as those associated with L1, L2 and L3 (Fig. 10). In addition, soil in L4 thickens similarly to soil in lynchets L1, L2 and L3. Soil thickness in L4 varies from approximately $50 \mathrm{~cm}$ at $30 \mathrm{~m}$ upslope of the field border to up to $150 \mathrm{~cm}$ near the border (Fig. 8c). This footslope lynchet is recurrent on cultivated areas. The L5 areas are not located upslope of any known field borders. They are on the hillslope shoulder where the slope gradient is gentle and soils are locally more developed (due 
to a deeper weathering of the bed-rock in more flat areas). Thus, some areas can present predictor variables similar to class 1 .

Undulations U1 to U6 are linked to field borders that have existed since at least 1836, and disappeared during the last campaign of land consolidation in 1967 (Fig. 10). Some cells of $\mathrm{U} 3$ are mapped as belonging to classes 1 or 0 by $\mathrm{CT}_{\text {soil }}$ (Fig. 9). U3 presents thinner soils than other undulations, but appears morphologically well-developed (Fig. 6 and Fig. 8a). Because some ranges of morphometric attribute values are intersected from one class to the other (Table 2), slight soil-thickness variations do not support the identification of U3 as undulations by $\mathrm{CT}_{\text {soil. }} \mathrm{U} 9$ is linked to a former field border that existed since at least 1836 and disappeared between 1946 and 1958. The geometrical network U10 is associated with successive borders that were very close to one another and had similar orientations. These borders disappeared after 1959. Undulations U7 to U10 were evidenced by both classification models and $\mathrm{U} 12$ by $\mathrm{CT}_{\text {topo }}$ only (Fig. 9). These five undulations are weakly developed in the field. Their associated field borders disappeared earlier than those linked to undulations which are better developed (U1 to U6). All of these undulations are linked to former field borders, have variable widths, and are roughly asymmetric.

The following two scenarios seem possible concerning the origin of these undulations. i) The undulations are former lynchets that were more or less developed and have been levelled after their associated field borders were destroyed, as suggested by [Bollinne, 1971] and [Houben, 2008] . The soil material redistribution could have occurred up- and downslope these landforms ( [Revel and Rouaud, 1985] and [Walling and Quine, 1991] ). ii) Undulations are headlands created by an asymmetric accumulation of soil due to tillage translocation on both sides of the borders (Callot, 1980 and Leturcq, 2008). Headlands have been mainly studied by the archaeology community in plains of northwestern Europe; they are more developed in planar context. They are often associated with field border networks created during the Middle Ages and have been active for several decades to a few centuries ( [Zadora-Rio, 1991] , Leturcq, 2008 and [Brown, 2009] ).

$\mathrm{U} 7$ and $\mathrm{U} 11$ are not related to any known field border (U11 being revealed by $\mathrm{CT}_{\text {topo }}$ only; Fig. 9). These linear landforms can be linked either to borders that disappeared before 1836 or to a specific management (e.g., repeated paths of tillage implement). Concerning the undifferentiated surfaces (Class 0 ), these areas could correspond either to locations where no field border has ever been established, or to former lynchets or undulations erased since the removal of associated borders.

Lynchet and undulation axes are predominantly perpendicular to the slope. Field borders are an efficient place to block soil material fluxes that are controlled totally (running water) or partially (tillage) by gravity ( [Van Dijk et al., 1996] and [Dabney et al., 1999] ). The mapping of lynchets and undulations through the application of $\mathrm{CT}_{\text {soil }}$ or $\mathrm{CT}_{\text {topo }}$ model revealed some undulations oriented in the slope direction (U8 and in the U10 undulations network, Fig. 10). In that case, only tillage erosion can explain an effective soil accumulation along those associated former borders. Tillage translocation is controlled first by the passage of the implement through the soil and then by the gravity effect ( [Lindstrom et al., 1990] and [Van Muysen et al., 2002] ). In the case of contour-line tillage, soil matter deposition occurs when tillage implements encounters field border oriented in the slope direction. This tends to suggest that U8 and U10 could be headlands originally. 
Considering discussion in this section and Section 4.1, we synthesize the informations about field borders and possible origins of the linear anthropogenic landform studied here in the Table 9. The possible origins concern: i) the soil accumulation processes before any field border removal and; ii) the influence of the C-horizon upper limit on the actual landform morphology in comparison with soil accumulation.

\subsection{Implications in soil mapping}

Results show that spatial variability of morphometric attributes and soil thickness is strongly influenced by successive field border networks in the study area. Each of the three landform classes identified here presents a distinguishable range of soil thickness values. Lynchet and undulation landforms correspond to thicker soil due to material deposition alongside present or former field borders (Section 4.2). Soil accumulation viewed in vertical section evolved as a pseudo right-angle triangle in lynchets and as a convex lens in undulations. The method developed here has the convenience of mapping the classification results. Therefore, this method could improve the spatial estimation of soil thickness variations and related soil properties over cultivated landscapes.

The CART algorithm applied to morphometric attributes and soil thickness $\left(\mathrm{CT}_{\text {soil }}\right)$ performs well for lynchet and undulation discrimination. Without soil thickness, the algorithm correctly identifies lynchets apart from undulations $\left(\mathrm{CT}_{\text {topo }}\right)$. However, similarities between maps performed from $\mathrm{CT}_{\text {soil }}$ and $\mathrm{CT}_{\text {topo }}$ models represent approximately $70 \%$ of the study area. Half of the dissimilarities are estimated as class 0 by the $\mathrm{CT}_{\text {soil }}$ model and as class 2 by the $\mathrm{CT}_{\text {topo }}$ model. Approximately $7 \%$ of these dissimilarities are affected to the opposite possibility. Thus, the $\mathrm{CT}_{\text {topo }}$ model tends to overestimate undulation areas in comparison with the more accurate $\mathrm{CT}_{\text {soil }}$ model (Section 4.2). We note that $\mathrm{CT}_{\text {topo }}$ correctly detects the location of all the features studied here (Fig. 11). Both applications appear to be good tools for the recognition and mapping of the studied anthropogenic landforms within cultivated hillslopes, especially lynchets.

The different applications of CART algorithm performed in this study demonstrate the importance of relations between soil thickness variations and lynchet and undulation landforms. Although these linear landforms are discrete in the landscape, they cover a significant part of the study area. According to the mapping performed with $\mathrm{CT}_{\text {soil }}$ model (Table 8 and Fig. 10), lynchets and undulations cover approximately $14 \%$ and $24 \%$ of the 16 ha site area, respectively. This means that almost $40 \%$ of the site area shows morphological evidence of an effective human impact on the spatial variability of soils. Lynchets and undulations appear as morphological indicators of human-induced soil accumulations.

Lynchets and undulations revealed by the $\mathrm{CT}_{\text {soil }}$ model contain about 6030 and $7517 \mathrm{~m}^{3}$ of additionally stored soil material, respectively (Table 8 ). These volumes represent $6.6 \%$ and $8.2 \%$ of the total soil material present in the study area. More than $6030 \mathrm{~m}^{3}$ of soil material could be then available to water and tillage translocations in this hillslope if field borders associated with current lynchets were destroyed in the immediate future. Although undulations are more discrete landforms than lynchets, they contain an equivalent volume of additionally stored soil material. Because undulations are associated with former field borders and lynchets to unchanged borders, undulations appear more frequently in the west of Europe. Politics, mechanisation and many other factors indeed stimulated important field border removal by land consolidation during the 1960s to 1980s in Western Europe (Vitikainen, 2004). These undulation landforms could be preferential areas for soil erosion by tillage, as 
wide gentle convexities within the landscape. Indeed, net soil loss by tillage translocation was demonstrated as being dependent on slope gradient changes. Erosion occurs on a convex slope, accumulation occurs on concave slopes, and a simple translation occurs on linear slopes ( [Lindstrom et al., 1992] and [Govers et al., 1996] ).

\section{Conclusion}

The aim of this study was to assess whether different types of anthropogenic landforms could be discriminated by their morphometric attributes and soil thicknesses. For this purpose, we developed a classification method based on a detailed field study carried out in a cultivated hillslope of the SW Parisian Basin (France). This method appears convenient because the classification models computed by the CART algorithm can be used as mapping tools.

We distinguished two different types of linear anthropogenic landforms in the study area, lynchets and undulations. They are easily distinguishable one from another by their morphometric attributes. Their ranges of soil thicknesses appear also statistically different: soil thicknesses are higher in lynchets than in undulations. These thicknesses are higher than those encountered in surrounding undifferentiated surfaces. Additionally, the shape of soil accumulation appears particular to each type of linear landform.

In contrast to lynchets, undulations are not easily distinguishable from undifferentiated surfaces by considering only morphometric attributes. Therefore, the distinction of undulations is less accurate than the distinction of lynchets. However, the undulation mapping is greatly improved when soil thickness is accounted for as predictor variable in the classification method.

Multi-temporal mapping of historic field system layouts shows that lynchets are associated with present field borders that have been established since at least 1836. The mapped undulations are linked to field borders that existed for a shorter time period and disappeared predominantly during the last campaign of land consolidation in 1967. Undulations appear to correspond to anthropogenic soil accumulations as lynchets. In perspective, the use of tracers as Cs-137 (half-time life of approximately 30.2 years) coupled to soil erosion modeling could be useful to precise the dynamics of both lynchet and undulation landforms since this last land consolidation.

Lynchets and undulations are rarely accounted for in landscape and regional-scale soil surveys. However, undulations are discrete and common linear landforms which can store an important amount of soil material. Our results would provide new perspectives in the soil mapping discipline if associated with new technologies for relief recording. For example, the LIDAR (LIght Detection And Ranging) allows the accurate recording of high-density topographic data in large areas ( [Brown et al., 2009] and [Rayburg et al., 2009] ). Such technologies are of particular interest for quick soil mapping techniques with fine resolution. LIDAR could be very efficient to detect lynchets and undulations in the landscape.

Based on an analysis of morphometric attributes of some representative anthropogenic landforms linked with soil thickening, the method developed here could improve the spatial estimation of soil thickness variations and related soil properties over large areas.

\section{Acknowledgements}


Financial support provided by the ANR (Agence Nationale de la Recherche) VMCS project LANDSOIL is gratefully acknowledged. The authors would like to thank Jean-Paul Bakyono and Isabel Pene-Galland for data collection in the field. This paper was much improved thanks to the comments of Peter Houben and an anonymous referee and thanks to Lauren Valverde who revised my english style.

\section{References}

Alcaydé et al., 1989 Alcaydé, G., Coubès, J., Macaire, J.-J., 1989. Feuille Loudun (513), Carte géologique de la France (1:50000), Orléans, BRGM..

Bellemlih, 1999 Bellemlih, S., 1999. Stocks particulaires holocènes et bilans de matières dans un bassin fluviatile en domaine sédimentaire - Le bassin du Négron, Sud-ouest du Bassin Parisien, France. Ph.D. thesis, Université de Tours, France..

Bolliger et al., 2007 J. Bolliger, H.H. Wagner and M.G. Turner, Identifying and quantifying landscape patterns in space and time, F. Kienast, O. Wildi, S. Ghosh, Editors, A Changing World: Challenges for Landscape Research, Springer, Dordrecht (2007), pp. 177-194

Bollinne, 1971 A. Bollinne, Les rideaux en Hesbaye gembloutoise - Etude morphologique et sédimentologique. Bulletin de la Société Géographique de Liège, 7 (1971), pp. 61-67.

Bourennane, 1997 Bourennane, H., 1997. Etude des lois de distribution spatiale des sols de Petite Beauce Application à la cartographie d'un horizon par couplage de méthodes morphométriques et géostatistiques. Ph.D. thesis, Université d'Orléans, France..

Boutin et al., 1990 Boutin, D., Froger, D., Rassineux, J., 1990. Feuille Loudun (1724-1624), Carte des sols du Département de la Vienne et de la région Centre au 1:50000, Chambre d'Agriculture de la Vienne - IGN - INRA..

Bracq and Delay, 1997 P. Bracq and F. Delay, Transmissivity and morphological features in a chalk aquifer: a geostatistical approach of their relationship. Journal of

Hydrology, 191 (1997), pp. 139-160.

Breiman et al., 1984 L. Breiman, J.H. Friedman, R.A. Olshen and J.S. Stone, Classification and Regression Trees, Wadsworth International Group, Belmont, California (1984).

Brown, 2009 A.G. Brown, Colluvial and alluvial response to land use change in Midland England: an integrated geoarchaeological approach. Geomorphology, 108 (2009), pp. 92 106.

Brown et al., 2009 A.G. Brown, C. Carey, G. Erkens, M. Fuchs, T. Hoffmann, J.-J. Macaire, K.-M. Moldenhauer and D.E. Walling, From sedimentary records to sediment budgets: multiple approaches to catchment sediment flux. Geomorphology, 108 (2009), pp. 35-47.

Callot, 1980 Callot, H.J., 1980. La plaine d'Alsace. Modelé agraire et parcellaire. Ph.D. thesis, Université de Nancy II, France.. 
Chaplot and Le Bissonnais, 2000 V. Chaplot and Y. Le Bissonnais, Field measurements of interril erosion under different slopes and plot sizes. Earth Surface Processes and Landforms, 25 (2000), pp. 145-153.

Chilès and Delfiner, 1999 J.P. Chilès and P. Delfiner, Geostatistics: modeling spatial uncertainty, Wiley, New York (1999).

Christensen and McElyea, 1988 L.A. Christensen and D.E. McElyea, Toward a general method of estimating productivity - soil depth response relationships. Journal of Soil and Water Conservation, 43 (1988), pp. 199-202.

Corbet, 1995 S.A. Corbet, Insects, plants and succession: advantages of long-term set-aside. Agriculture, Ecosystems and Environment, 53 (1995), pp. 201-217.

Dabney et al., 1999 S.M. Dabney, Z. Liu, M. Lane, J. Douglas, J. Zhu and D.C. Flanagan, Landscape benching from tillage erosion between grass hedges. Soil and Tillage Research, 51 (1999), pp. 219-231.

De Alba, 2003 S. De Alba, Simulating long-term soil redistribution generated by different patterns of mouldboard ploughing in landscapes of complex topography. Soil and Tillage Research, 71 (2003), pp. 71-86.

De Moor et al., 2008 J.J.W. De Moor, C. Kasse, R. Van Balen, J. Vanderberghe and J. Wallinga, Human and climate impact on catchment development during the Holocene-Geul River, the Netherlands. Geomorphology, 98 (2008), pp. 316-339

Derruau, 1962 M. Derruau, Précis de Géomorphologie, Masson \& Cie, Paris (1962).

FAO, 1998 FAO, World Reference Base for Soil Resources World Soil Resources Report No 84, FAO, Rome (1998).

Farina, 2006 A. Farina, Principle and methods in landscape ecology - towards a science of landscape, Kluwer, Dordrecht (2006).

Follain, 2005 Follain, S., 2005. Effet du réseau bocager sur l'organisation des sols. Redistributions des sols et stockage en carbone organique. Ph.D. thesis, Ecole Nationale Supérieure d'Agronomie de Rennes, France..

Follain et al., 2006 S. Follain, B. Minasny, A.B. McBratney and C. Walter, Simulation of soil thickness evolution in a complex agricultural landscape at fine spatial and temporal scales. Geoderma, 133 (2006), pp. 71-86.

Follain et al., 2007 S. Follain, C. Walter, A. Legout, B. Lemercier and G. Dutin, Induced effect of hedgerow networks on soil organic carbon storage within an agricultural landscape. Geoderma, 142 (2007), pp. 80-95.

Gerrard, 1981 J. Gerrard, Soils and landforms: an integration of geomorphology and pedology, George Allen \& Unwin, London and Boston (1981). 
Gessler et al., 1995 P.E. Gessler, I.D. Moore, N.J. McKenzie and P.J. Ryan, Soil-landscape modelling and spatial prediction of soil attributes. International Journal of Geographical Information Science, 94 (1995), pp. 421-432

Goovaerts, 1997 P. Goovaerts, Geostatistics for Natural Resources Evaluation, Oxford University Press, New York (1997).

Govers et al., 1996 G. Govers, T.A. Quine, P.J.J. Desmet and E. Walling, The relative contribution of soil tillage and overland flow erosion to soil redistribution on agricultural land. Earth Surface Processes and Landforms, 21 (1996), pp. 929-946.

Govers et al., 1999 G. Govers, D.A. Lobb and T.A. Quine, Tillage erosion and translocation: emergence of a new paradigm in soil erosion research. Soil and Tillage Research, 51 (1999), pp. 167-174.

Grinand et al., 2008 C. Grinand, D. Arrouays, B. Laroche and M.P. Martin, Extrapolating regional soil landscapes from an existing soil map: sampling intensity, validation procedures, and integration of spatial context. Geoderma, 143 (2008), pp. 180-190.

Heimsath et al., 1999 A.M. Heimsath, W.E. Dietrich, K. Nishiizumi and R.C. Finkel, Cosmogenic nuclides, topography, and the spatial variation of soil depth.

Geomorphology, 27 (1999), pp. 151-172.

Hooke, 1988 D. Hooke, Early forms of open-field agriculture in England. Geografiska Annaler, 70 B 1 (1988), pp. 123-131.

Houben, 2008 P. Houben, Scale linkage and contingency effects of field-scale and hillslopescale controls of long-term soil erosion: anthropogeomorphic sediment flux in agricultural loess watersheds of Southern Germany. Geomorphology, 101 (2008), pp. 172-191.

Huggett, 1975 R.J. Huggett, Soil landscape systems: a model of soil genesis. Geoderma, 13 (1975), pp. 1-22.

Huggett, 1997 R.J. Huggett, Environmental change: the evolving ecosphere, Routledge, London (1997).

Isambert et al., 1997 M. Isambert, H. Bourennane, A. Couturier, D. King and M. Jamagne, Analyse de la distribution des sols en fonction de l'orientation de la pente. Application à un secteur du Vexin français. Géologie de la France, 4 (1997), pp. 55-67.

Jenny, 1941 H. Jenny, Factors of Soil Formation, McGraw-Hill, New York (1941).

King et al., 1999 D. King, H. Bourennane, M. Isambert and J.-J. Macaire, Relationship of the presence of a non-calcareous clay-loam horizon to DEM attributes in a gently sloping area. Geoderma, 89 (1999), pp. 95-111.

Knapen et al., 2008 A. Knapen, J. Poesen, G. Govers and S. De Baets, The effect of conservation tillage on runoff erosivity and soil erodibility during concentrated flow. Hydrological Processes, 22 (2008), pp. 1497-1508. 
Kosmas et al., 2001 C. Kosmas, S. Gerontidis, M. Marathianou, B. Detsis, T. Zafiriou, W. Van Muysen, G. Govers, T.A. Quine and K. Van Oost, The effects of tillage displaced soil on soil properties and wheat biomass. Soil and Tillage Research, 58 (2001), pp. 31-44.

Lagacherie, 1992 Lagacherie, P., 1992. Formalisation des lois de distribution des sols pour automatiser la cartographie pédologique à partir d'un secteur pris comme référence. Ph.D. Thesis, Université de Montpellier, France..

Leturcq, 2008 Leturcq, S., 2008. Fonction et devenir d'un réseau invisible: les crêtes de labour dans les terroirs beaucerons (XIVe-XXe siècles). COST du Mans. Compatangelo-Soussignan, R., Bertrand, J.R., Chapman, J., Laffont, P.Y., Rennes, France, pp. 163-174..

Lindstrom et al., 1990 M.J. Lindstrom, W.W. Nelson, T.E. Schumacher and G.D. Lemme, Soil movement by tillage as affected by slope. Soil and Tillage Research, 17 (1990), pp. 255-264.

Lindstrom et al., 1992 M.J. Lindstrom, W.W. Nelson and T.E. Schumacher, Quantifying tillage erosion rates due to moldbard plowing. Soil and Tillage Research, 24 (1992), pp. 243-255.

Macaire et al., 2002 J.-J. Macaire, S. Bellemlih, C. Di Giovanni, P. De Luca, L. Visset and J. Bernard, Sediment yield and storage variations in the Negron river catchment (South western Parisian Basin, France) during the Holocene period. Earth Surface Processes and Landforms, 27 (2002), pp. 991-1009

Macaire et al., 2010 J.-J. Macaire, A. Fourmont, J. Argant, J.-G. Bréhéret, F. Hinschberger and F. Trément, Quantitative analysis of climate versus human impact on sediment yield since the Lateglacial: the Sarliève paleolake catchment (France). The Holocene, 20 (2010), pp. 497-516.

McBratney et al., 2003 A.B. McBratney, M.L. Mendonça Santos and B. Minasny, On digital soil mapping. Geoderma, 117 (2003), pp. 3-52.

Meeus et al., 1990 J.H.H. Meeus, M.P. Wijermans and M.J. Vroom, Agricultural landscapes in Europe and their transformation. Landscape and Urban Planning, 18 (1990), pp. 289352.

Odeh et al., 1994 I.O.A. Odeh, A.B. McBratney and D.J. Chittleborough, Spatial prediction of soil properties from landform attributes derived from a digital elevation model.

Geoderma, 63 (1994), pp. 197-214.

Papendick and Miller, 1977 R.I. Papendick and D.E. Miller, Conservation tillage in Pacific Northwest. Journal of Soil and Water Conservation, 32 (1977), pp. 49-56.

Power et al., 1981 J.F. Power, F.M. Sandoval, R.E. Ries and S.D. Derrill, Effects of topsoil and subsoil thickness on soil water content and crop production on a disturbed soil. Soil Science Society of America Journal, 45 (1981), pp. 124-129. 
R Development Core Team, 2010 R Development Core Team, R: A language and environment for statistical computing, R Foundation for Statistical Computing, Vienna, Austria (2010)

Rayburg et al., 2009 S. Rayburg, M. Thoms and M. Neave, A comparison of digital elevation models generated from different data sources. Geomorphology, 106 (2009), pp. 261-270.

Revel and Rouaud, 1985 J.C. Revel and M. Rouaud, Mécanismes et importance des remaniements dans le Terrefort toulousain (bassin aquitain, France). Pédologie, 35 (1985), pp. 171-189.

Salvador-Blanes, 2002 Salvador-Blanes, S., 2002. Déterminisme de la distribution spatiale des éléments majeurs et traces dans les sols en contexte métamorphique (Plateau d'Aigurande, nord du Massif Central, France). Ph.D. thesis, Université de Tours, France..

Salvador-Blanes et al., 2006 S. Salvador-Blanes, S. Cornu, A. Couturier, D. King and J.-J. Macaire, Morphological and geochemical properties of soil accumulated in hedge-induced terraces in the Massif Central, France. Soil and Tillage Research, 85 (2006), pp. 62-77.

Shatar and McBratney, 1999 T.M. Shatar and A.B. McBratney, Empirical modeling of relationships between sorghum yield and soil properties. Precision Agriculture, 1 (1999), pp. 249-276.

Steinberg and Colla, 1995 D. Steinberg and P. Colla, CART: tree-structured non-parametric data analysis, Salford Systems, San Diego, California, USA (1995).

Szilassi et al., 2006 P. Szilassi, G. Jordan, A. Van Rompaey and G. Csillag, Impacts of historical land use changes on erosion and agricultural soil properties in the Kali Basin at the Lake Balaton, Hungary. Catena, 68 (2006), pp. 96-108.

Taylor, 1975 C.C. Taylor, Fields in the English Landscape, London, (1975).

Turner et al., 2001 M.G. Turner, R.H. Gardner and R.V. O'Neill, Landscape ecology in theory and practice: pattern and process, Springer-Verlag, New York, USA (2001).

Van Dijk et al., 1996 P.M. Van Dijk, F.F.P.M. Kwaad and M. Klapwijk, Retention of water and sediment by grass strips. Hydrological Processes, 10 (1996), pp. 1069-1080.

Van Dijk et al., 2005 P.M. Van Dijk, A.-V. Auzet and M. Lemmel, Rapid assessment of field erosion and sediment transport pathways in cultivated catchments after heavy rainfall events. Earth Surface Processes and Landforms, 30 (2005), pp. 169-182.

Van Muysen et al., 2002 W. Van Muysen, G. Govers and K. Van Oost, Identification of important factors in the process of tillage erosion: the case of mouldboard tillage. Soil and Tillage Research, 65 (2002), pp. 77-93.

Van Oost et al., 2000 K. Van Oost, G. Govers and P.J.J. Desmet, Evaluating the effects of changes in landscape structure on soil erosion by water and tillage. Landscape

Ecology, 15 (2000), pp. 577-589. 
Van Wesemael et al., 2000 B. Van Wesemael, M. Mulligan and J. Poesen, Spatial patterns of soil-water balance on intensively cultivated hillslopes in a semi-arid environment: the impact of rock fragments and soil thickness. Hydrological Processes, 14 (2000), pp. 1811-1828. |

Vandaele et al., 1996 K. Vandaele, J. Poesen, G. Govers and B. Van Wesemael, Geomorphic threshold conditions for ephemeral gully incision. Geomorphology, 16 (1996), pp. 161-173.

Vitikainen, 2004 A. Vitikainen, An overview of land consolidation in Europe. Nordic Journal of Surveying and Real Estate Research, 1 (2004), pp. 25-44.

Walling and Quine, 1991 D.E. Walling and T.A. Quine, Use of 137Cs measurements to investigate soil erosion on arable field in the UK: potential applications and limitations. Journal of Soil Science, 42 (1991), pp. 147-165.

Yoo et al., 2006 K. Yoo, R. Amundson, A.M. Heimsath and W.E. Dietrich, Spatial patterns of soil organic carbon on hillslopes: integrating geomorphic processes and the biological $\mathrm{C}$ cycle. Geoderma, 130 (2006), pp. 47-65.

Zadora-Rio, 1991 E. Zadora-Rio, Les terroirs médiévaux dans le Nord-Ouest de l'Europe, J. Guilaine, Editor, Pour une Archéologie agraire, Paris (1991), pp. 165-192.

Zevenbergen and Thorne, 1987 L.W. Zevenbergen and C.R. Thorne, Quantitative analysis of land surface topography. Earth Surface Processes and Landforms, 12 (1987), pp. 47-56 


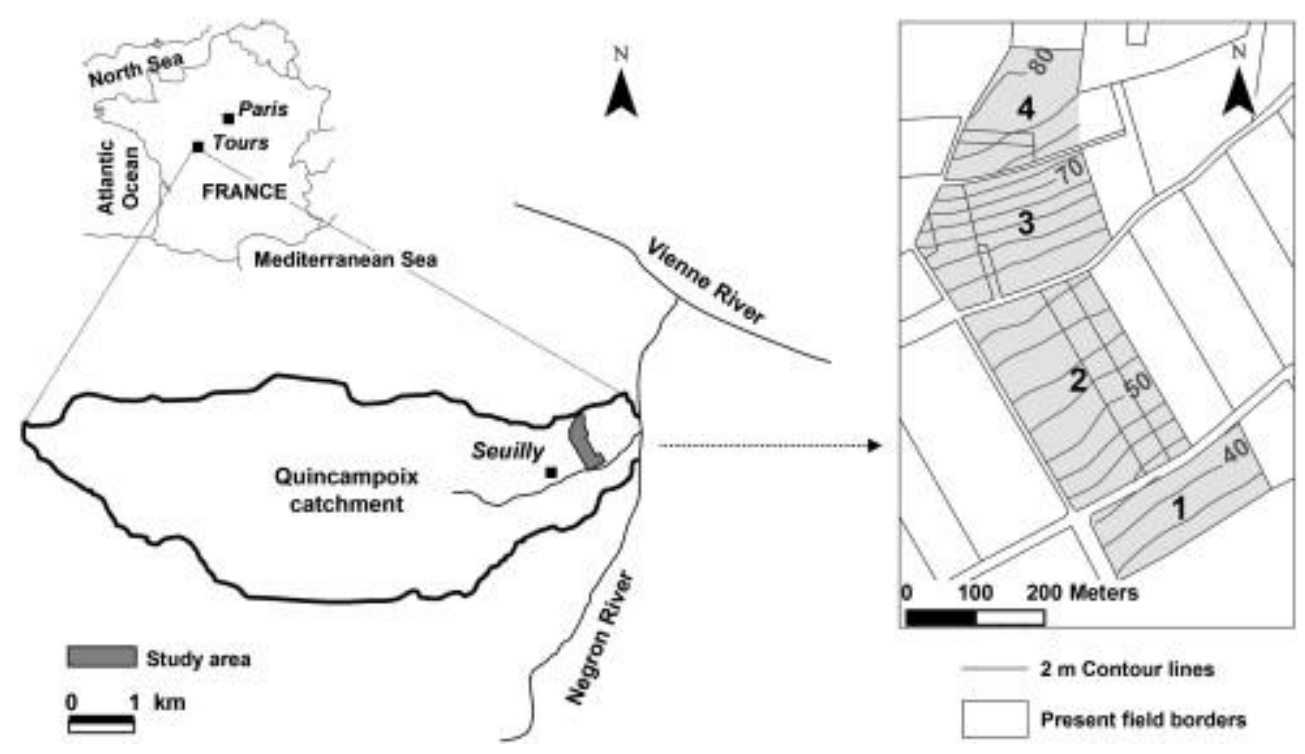

Fig. 1. : Location and topography of the study area.

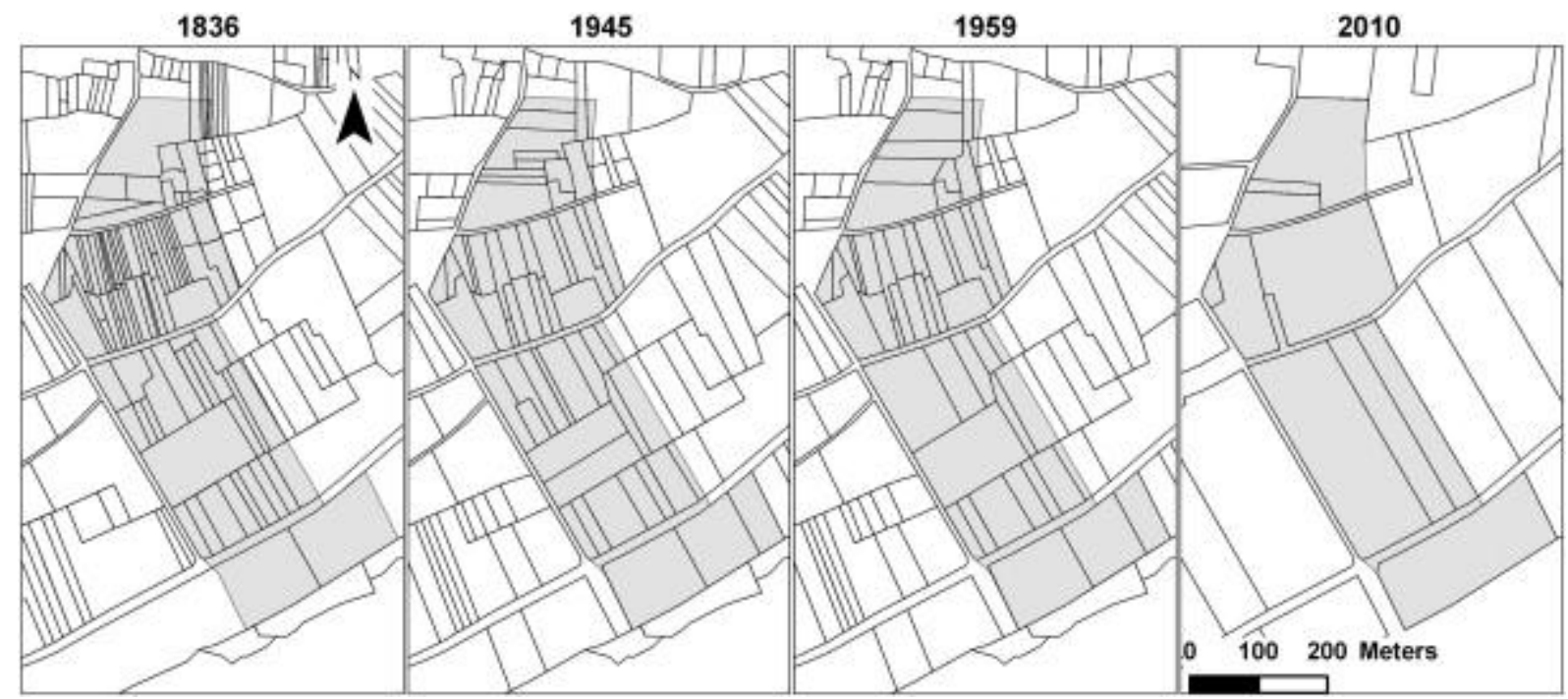

Fig. 2. : Field border networks in 1836, 1945, 1959 and 2010. 

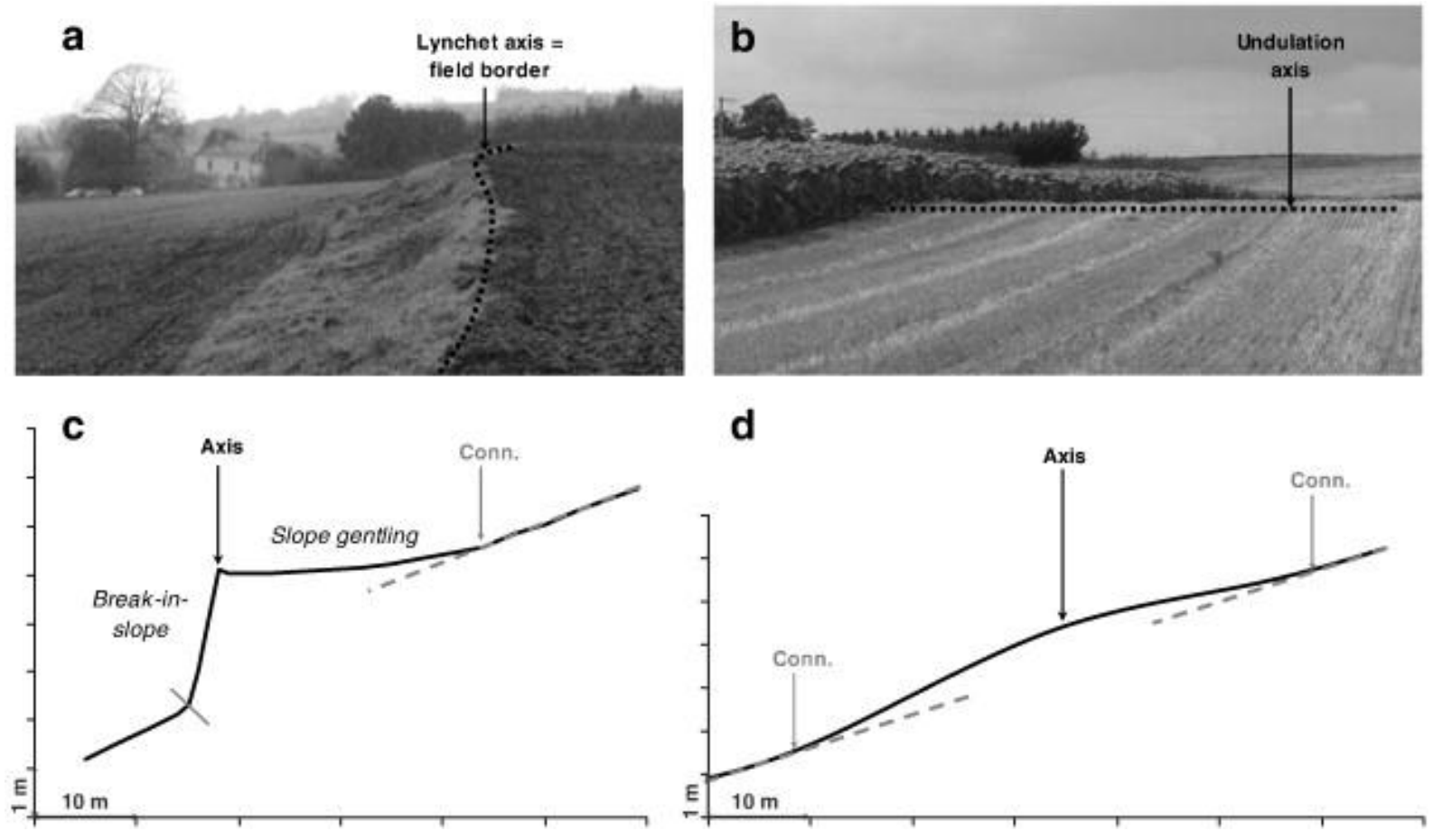

Fig. 3. : Illustrations of the two types of linear anthropogenic landforms present in the study area: (a) and (c) present a view and a topographic cross-section of a lynchet; and (b) and (d) present a view and a topographic cross-section of an undulation ("Conn.": connection). 


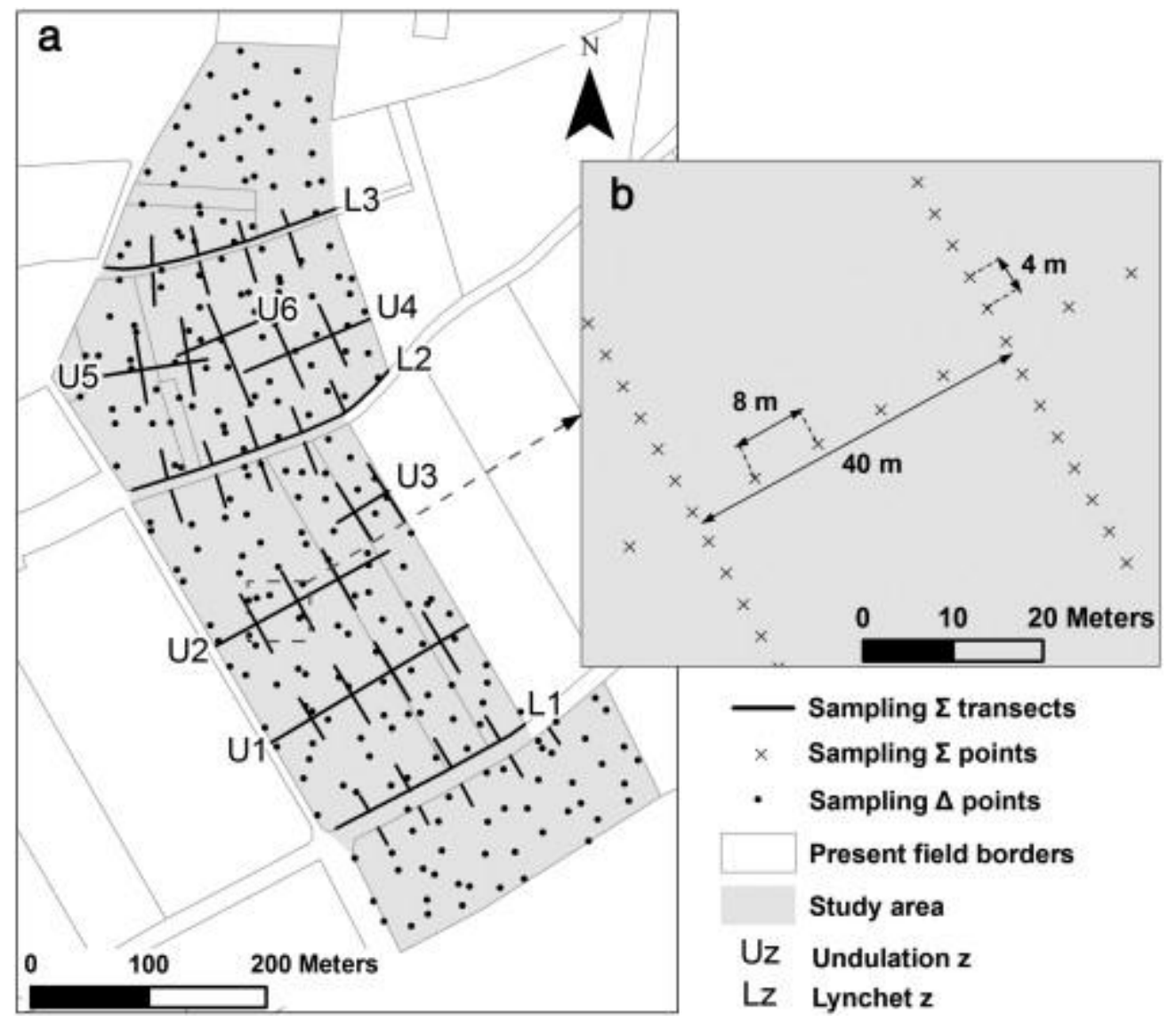

Fig. 4. : Soil sampling schemes: (a) samplings $\Sigma$ and $\Delta$ in the whole study area; and (b) zoom on sampling $\Sigma$ scheme in an undulation (U2). 

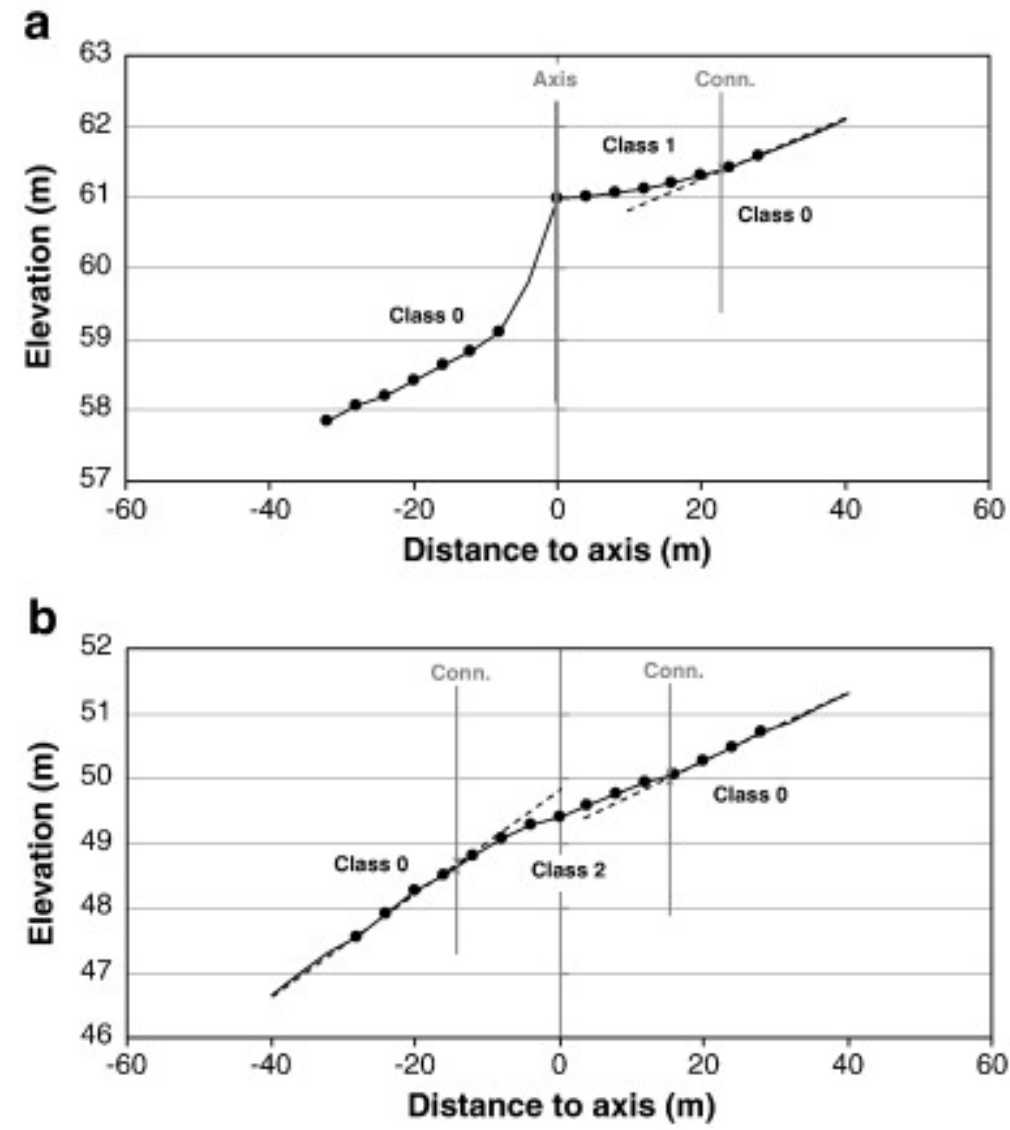

Fig. 5. : Illustrations of the classification method for perpendicular transects of soil sampling scheme $\Sigma$ : (a) perpendicular transect on a lynchet and (b) on an undulation (dots: soil samples locations, "Conn": connection). 
Table 1. Summary statistics of morphometric attributes and soil thickness calculated from the total dataset of 734 points.

\begin{tabular}{|l|l|l|l|l|l|}
\hline Variable & Unit & Min & Mean & Max & S.D. \\
\hline Slope & $\%$ & 0.16 & 5.31 & 11.90 & 1.53 \\
\hline Curvature $^{\mathrm{a}}$ & $\mathrm{m}^{-1}$ & -1.00 & -0.03 & 1.18 & 0.19 \\
\hline Profile curvature $^{\mathrm{a}}$ & $\mathrm{m}^{-1}$ & -0.97 & 0.03 & 1.03 & 0.17 \\
\hline Planform curvature $^{\mathrm{a}}$ & $\mathrm{m}^{-1}$ & -0.32 & 0.00 & 0.47 & 0.07 \\
\hline Soil thickness & $\mathrm{m}$ & 0.22 & 0.62 & 2.23 & 0.33 \\
\hline
\end{tabular}

${ }^{\mathrm{a}}$ The negative values of curvature and planform curvature mean for concavity and positive values for convexity. The negative values of profile curvature mean for convexity and positive values for concavity.

${ }^{\mathrm{b}}$ S.D: Standard Deviation. 


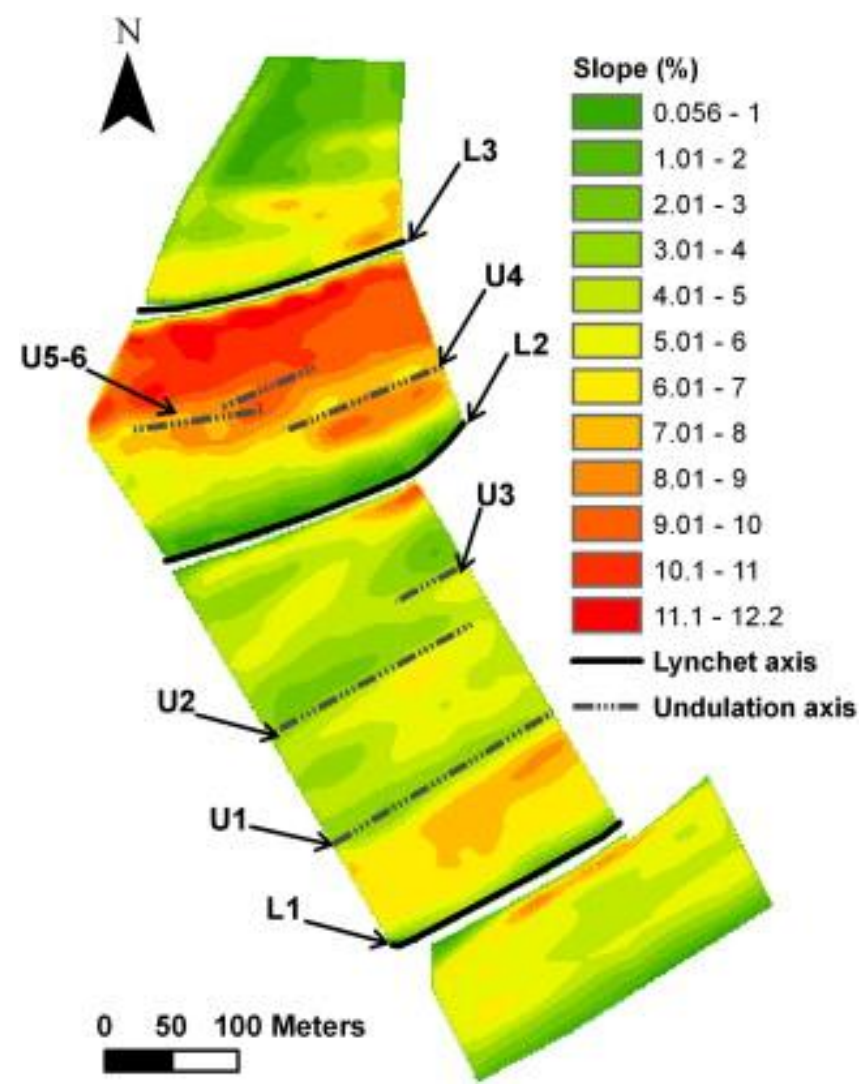

Fig. 6. : Map of slope gradient within the study area and location of lynchets and undulations axis. 


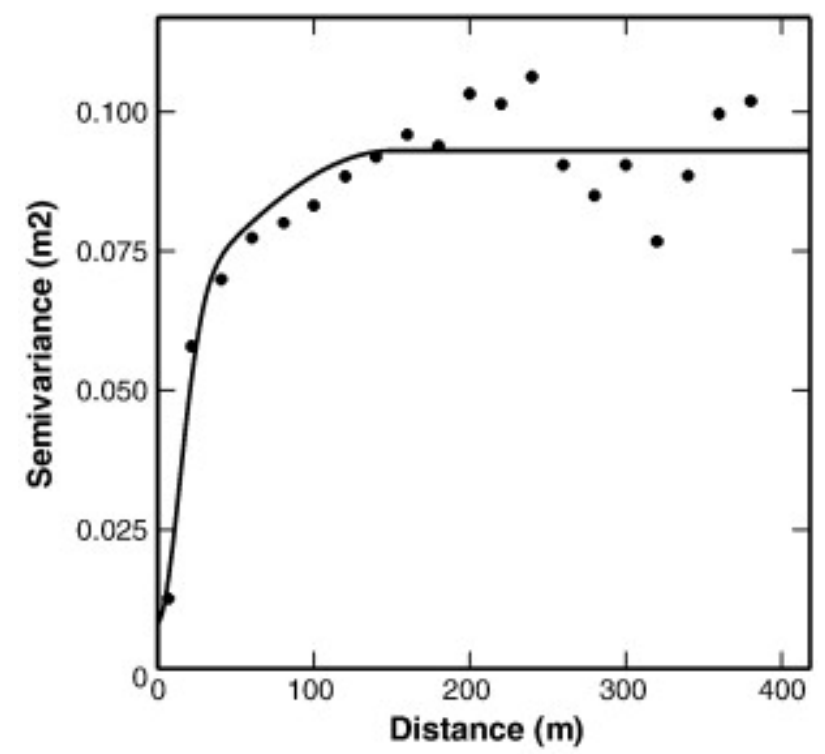

Fig. 7. : Experimental variogram of soil thickness (dots) and the theoretical model fits (solid line). 


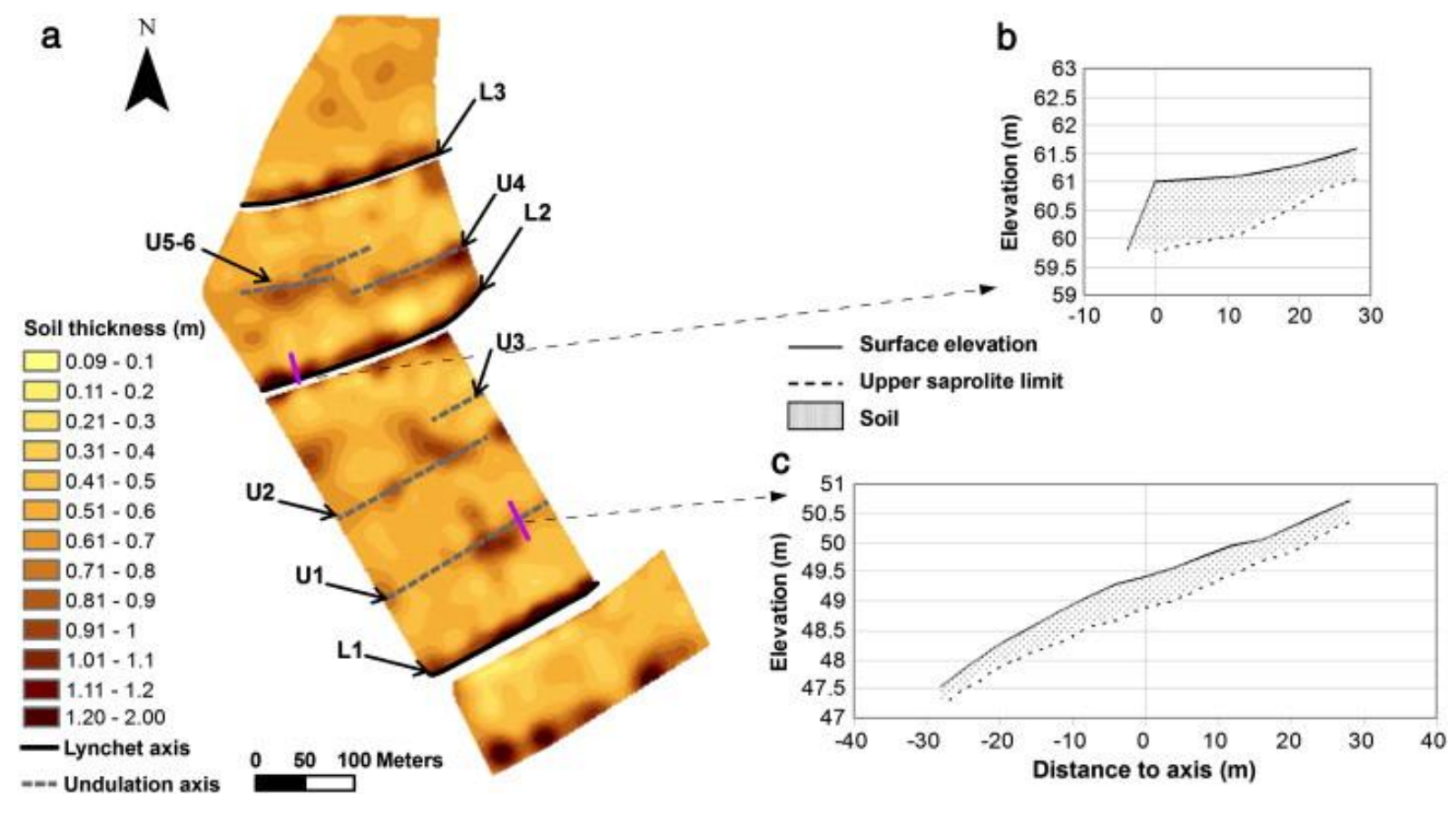

Fig. 8. : Soil thickness variability within the study area: (a) map of soil thickness estimated from the 586 points of the estimation dataset. Illustrations of characteristic topographic crosssection and soil thickness evolution (b) in a lynchet and (c) in an undulation. 
Table 2. Summary statistics of morphometric attributes and soil thickness in each expert class.

\begin{tabular}{|c|c|c|c|c|c|c|c|c|c|c|c|c|c|c|c|c|}
\hline \multirow[t]{2}{*}{ Class } & \multirow[t]{2}{*}{ Size } & \multicolumn{3}{|c|}{ Slope (\%) } & \multicolumn{3}{|c|}{ Curvature $\left(\mathbf{m}^{-1}\right)^{\mathbf{a}}$} & \multicolumn{3}{|c|}{$\begin{array}{l}\text { Profile curvature } \\
\left(\mathbf{m}^{-1}\right)^{\mathbf{a}}\end{array}$} & \multicolumn{3}{|c|}{$\begin{array}{l}\text { Planform } \\
\text { curvature }\left(\mathbf{m}^{-1}\right)^{\mathbf{a}}\end{array}$} & \multicolumn{3}{|c|}{ Soil thickness (m) } \\
\hline & & Min & $\begin{array}{l}\text { Mean } \\
\text { (S.Db) }\end{array}$ & Max & Min & $\begin{array}{l}\text { Mean } \\
\text { (S.Db) }\end{array}$ & Max & Min & $\begin{array}{l}\text { Mean } \\
\text { (S.Db }\end{array}$ & $\operatorname{Max}$ & Min & $\begin{array}{l}\text { Mean } \\
\text { (S.Db) }\end{array}$ & Max & Min & $\begin{array}{l}\text { Mean } \\
\text { (S.Db) }\end{array}$ & Max \\
\hline 0 & 389 & 0.84 & $\begin{array}{l}6.04 \\
(2.5)\end{array}$ & 11.90 & \begin{tabular}{|l|}
- \\
0.35
\end{tabular} & $\begin{array}{l}-0.02 \\
(0.2)\end{array}$ & 1.18 & 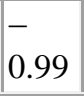 & $\begin{array}{l}0.02 \\
(0.2)\end{array}$ & 0.33 & 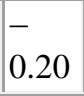 & $\begin{array}{l}0.00 \\
(0.1)\end{array}$ & 0.30 & 0.22 & $\begin{array}{l}0.45 \\
(0.2)\end{array}$ & 1.30 \\
\hline 1 & 139 & 0.16 & $\begin{array}{l}2.62 \\
(2.0)\end{array}$ & 9.35 & \begin{tabular}{|l|}
- \\
1.01
\end{tabular} & $\begin{array}{l}-0.20 \\
(0.2)\end{array}$ & 0.32 & \begin{tabular}{|l|}
- \\
0.14
\end{tabular} & $\begin{array}{l}0.18 \\
(0.2)\end{array}$ & 1.03 & 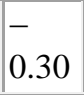 & $\begin{array}{l}-0.01 \\
(0.1)\end{array}$ & 0.47 & 0.45 & $\begin{array}{l}1.08 \\
(0.4)\end{array}$ & 2.23 \\
\hline 2 & 206 & 2.37 & $\begin{array}{l}5.73 \\
(2.2)\end{array}$ & 10.32 & \begin{tabular}{|l|}
- \\
0.32
\end{tabular} & $\begin{array}{l}0.05 \\
(0.1)\end{array}$ & 0.36 & $\mid$\begin{tabular}{l|}
- \\
0.28
\end{tabular} & $\begin{array}{l}-0.04 \\
(0.1)\end{array}$ & 0.33 & 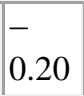 & $\begin{array}{l}0.00 \\
(0.1)\end{array}$ & 0.32 & 0.35 & $\begin{array}{l}0.62 \\
(0.2)\end{array}$ & 1.30 \\
\hline
\end{tabular}

${ }^{\mathrm{a}}$ The negative values of curvature and planform curvature mean for concavity and positive values for convexity. The negative values of profile curvature mean for convexity and positive values for concavity.

${ }^{\mathrm{b}}$ S.D: Standard deviation.

Table 3. Tukey's HSD (Honestly Significance Differences) test results ( $\alpha$ level: 0.05).

\begin{tabular}{|l|l|l|l|l|l|}
\hline Contrast & Slope & Curvature & Profile curvature & Planform curvature & Soil thickness \\
\hline 1 vs. 0 & Yes & Yes & Yes & Yes & Yes \\
\hline 1 vs. 2 & Yes & Yes & Yes & Yes & Yes \\
\hline 2 vs.0 & No & Yes & Yes & No & Yes \\
\hline
\end{tabular}

Table 4. Confusion matrix on calibration dataset $\left(\mathrm{CT}_{\text {soil }}\right.$ model $)$.

\begin{tabular}{|l|l|l|l|l|l|}
\hline Class & $\mathbf{0}^{\prime}$ & $\mathbf{1}^{\prime}$ & $\mathbf{2}^{\prime}$ & Total & \% correct(a) \\
\hline 0 & 279 & 11 & 29 & 319 & 87.5 \\
\hline 1 & 12 & 85 & 3 & 100 & 85.0 \\
\hline 2 & 40 & 0 & 127 & 167 & 76.0 \\
\hline Total & 331 & 96 & 159 & 586 & 83.8 \\
\hline
\end{tabular}

' means for estimated class.

${ }^{\text {a }}$ Corresponds to the ratio of objects correctly classified within the class by the CT model.

Table 5. Validation procedure results from $\mathrm{CT}_{\text {soil }}$ model.

\begin{tabular}{|l|l|l|l|l|l|l|l|}
\hline Class & $\mathbf{0}^{\prime}$ & $\mathbf{1}^{\prime}$ & $\mathbf{2}^{\prime}$ & Total & \% correct \\
\hline 0 & 56 & 6 & 8 & 70 & 80.0 \\
\hline 1 & 1 & 36 & 2 & 39 & 92.3 \\
\hline 2 & 6 & 2 & 31 & 39 & 79.5 \\
\hline Total & 63 & 44 & 41 & 148 & 83.1 \\
\hline
\end{tabular}

' means for estimated class.

${ }^{\mathrm{a}}$ Corresponds to the ratio of objects correctly classified within the class by the CT model. 


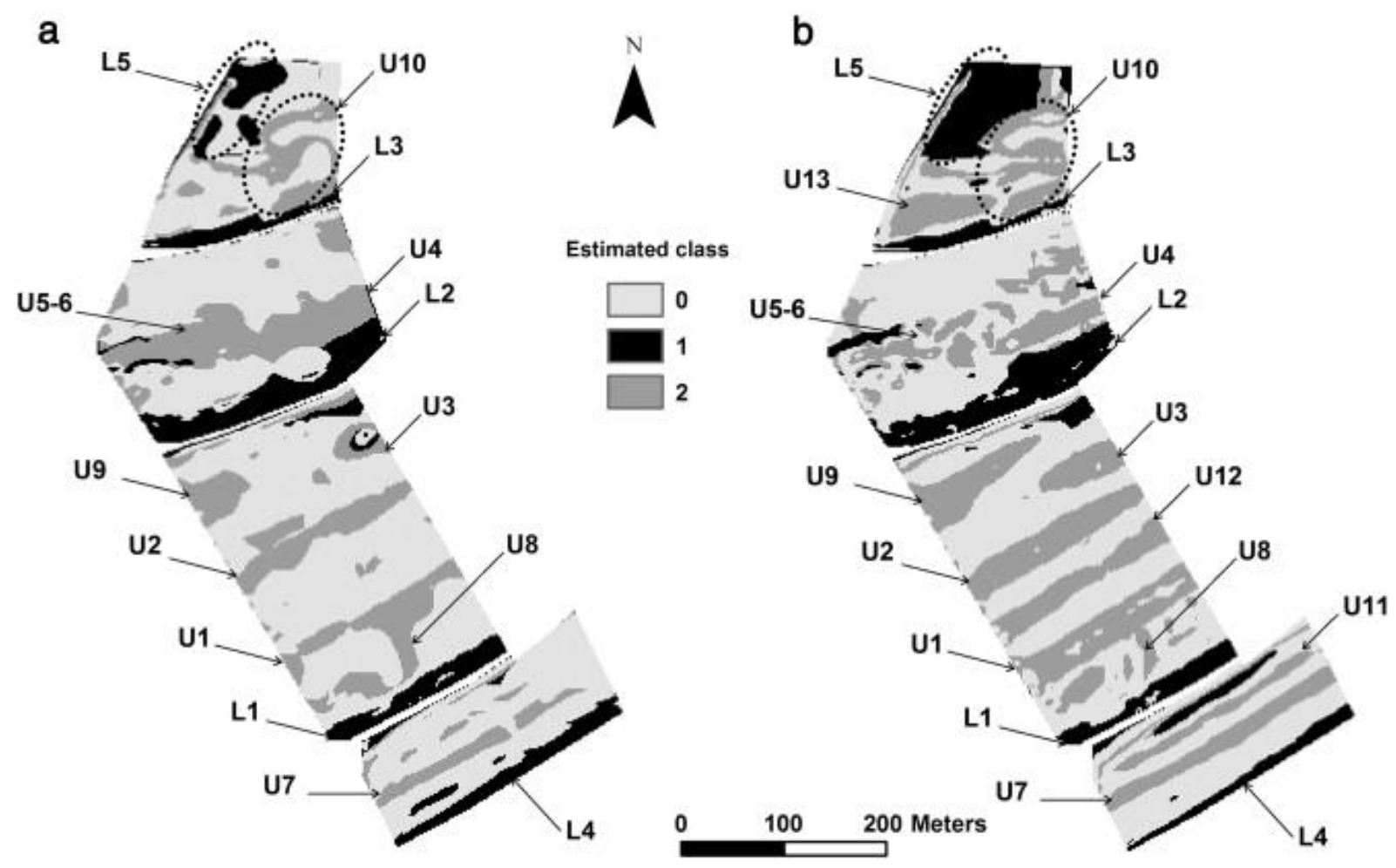

Fig. 9. : Maps of (a) $\mathrm{CT}_{\text {soil }}$ model and (b) $\mathrm{CT}_{\text {topo }}$ model results in the study area. Class 0: undifferentiated area. Class 1: lynchet. Class 2: undulation. 
Table 6. Confusion matrix on the subset of calibration dataset including only classes 1 and 2 $\left(\mathrm{CT}_{\text {topo }}\right.$ model).

\begin{tabular}{|l|l|l|l|l|}
\hline Class & $\mathbf{1}^{\prime}$ & $\mathbf{2}^{\prime}$ & Total & \% correct \\
\hline 1 & 92 & 8 & 100 & 92.0 \\
\hline 2 & 1 & 166 & 167 & 99.4 \\
\hline Total & 93 & 174 & 267 & 96.6 \\
\hline
\end{tabular}

' means for estimated class.

${ }^{\text {a }}$ Corresponds to the ratio of objects correctly classified within the class by the CT model.

Table 7. Validation procedure results from $\mathrm{CT}_{\text {topo }}$ model.

\begin{tabular}{|l|l|l|l|l|l|}
\hline Class & $\mathbf{0}^{\prime}$ & $\mathbf{1}^{\prime}$ & $\mathbf{2}^{\prime}$ & Total $^{\prime}$ & \% correct $^{\mathbf{a}}$ \\
\hline 0 & 44 & 7 & 19 & 70 & 62.9 \\
\hline 1 & 5 & 32 & 2 & 39 & 82.1 \\
\hline 2 & 15 & 1 & 23 & 39 & 59.0 \\
\hline Total & 64 & 40 & 44 & 148 & 66.9 \\
\hline
\end{tabular}

' means for estimated class.

${ }^{\mathrm{a}}$ Corresponds to the ratio of objects correctly classified within the class by the CT model.

Table 8. Soil material accumulated in lynchets and undulations revealed by $\mathrm{CT}_{\text {soil }}$ model.

\begin{tabular}{|c|c|c|c|c|c|c|}
\hline \multirow[t]{2}{*}{$\begin{array}{l}\text { Type of } \\
\text { landform }\end{array}$} & \multirow[t]{2}{*}{$\begin{array}{l}\text { Accumulation } \\
\text { area }\left(\mathbf{m}^{2}\right)\end{array}$} & \multirow[t]{2}{*}{$\begin{array}{l}\% \text { of total } \\
\text { study area }\end{array}$} & \multicolumn{2}{|c|}{$\begin{array}{l}\text { Storage } \\
\text { thickness } t_{i}(\mathrm{~m})\end{array}$} & \multirow[t]{2}{*}{$\begin{array}{l}\text { Stored volume } \\
V_{\text {st }}\left(\mathbf{m}^{3}\right)\end{array}$} & \multirow[t]{2}{*}{$\begin{array}{l}\% \text { of total soil } \\
\text { material in study area }\end{array}$} \\
\hline & & & Min & Max & & \\
\hline Lynchets & 22148 & 14.3 & 0.00 & 1.40 & 6031 & 6.6 \\
\hline Undulations & 37856 & 24.3 & 0.00 & 0.78 & 7517 & 8.2 \\
\hline
\end{tabular}




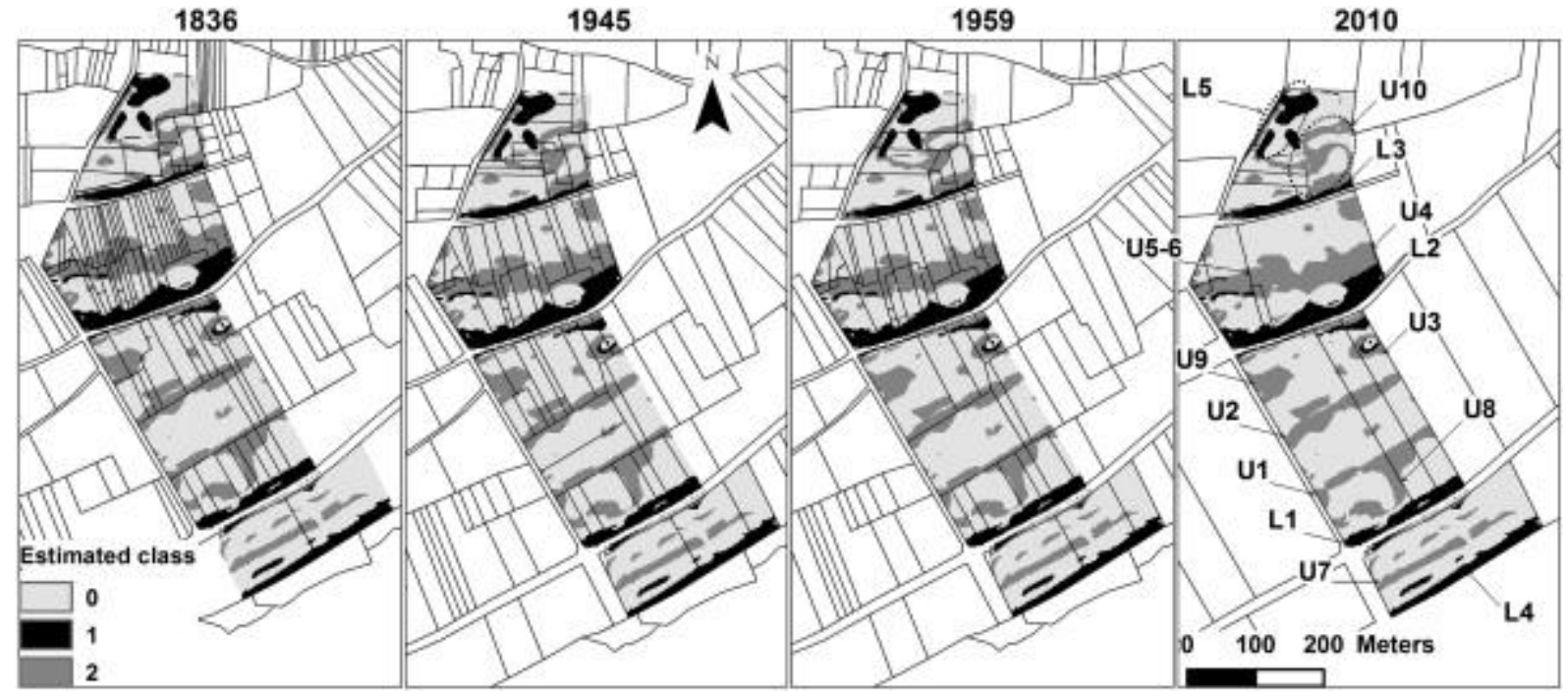

Fig. 10. : Maps of $\mathrm{CT}_{\text {soil }}$ model results and field border networks of 1836, 1945, 1959 and 2010. Class 0: undifferentiated area. Class 1: lynchet. Class 2: undulation. 
Table 9. Anthropogenic linear landforms, associated field borders and possible origins.

\begin{tabular}{|c|c|c|c|c|c|}
\hline \multirow[t]{2}{*}{$\begin{array}{l}\text { Anthropogenic } \\
\text { linear landform }\end{array}$} & \multirow{2}{*}{$\begin{array}{l}\text { Association with a } \\
\text { known field } \\
\text { border }\end{array}$} & \multicolumn{2}{|c|}{$\begin{array}{l}\text { Field border } \\
\text { duration }\end{array}$} & \multirow{2}{*}{$\begin{array}{l}\text { Possible soil } \\
\text { deposition } \\
\text { processes }\end{array}$} & \multirow{2}{*}{$\begin{array}{l}\text { Possible } \\
\text { substrate top } \\
\text { influence }\end{array}$} \\
\hline & & From $^{\text {a }}$ & To $\mathbf{b}^{\underline{\mathbf{b}}}$ & & \\
\hline L1 & Yes & $\begin{array}{l}\min . \\
1836\end{array}$ & Present & Water + Tillage & $?$ \\
\hline L2 & Yes & $\begin{array}{l}\min . \\
1836\end{array}$ & Present & Water + Tillage & $?$ \\
\hline L3 & Yes & $\begin{array}{l}\min . \\
1836\end{array}$ & Present & Water + Tillage & $?$ \\
\hline L4 & Yes & $\begin{array}{l}\min . \\
1836\end{array}$ & Present & Water + Tillage & $?$ \\
\hline U1 & Yes & $\min$. & 1967 & Water + Tillage & Yes \\
\hline $\mathrm{U} 2$ & Yes & $\begin{array}{l}\min . \\
1836\end{array}$ & 1967 & Water + Tillage & Yes \\
\hline U3 & Yes & $\begin{array}{l}\min . \\
1836\end{array}$ & 1967 & Water + Tillage & Yes \\
\hline U4 & Yes & $\begin{array}{l}\min . \\
1836\end{array}$ & 1967 & Water + Tillage & No \\
\hline U5 & Yes & $\begin{array}{l}\min . \\
1836\end{array}$ & 1967 & Water + Tillage & No \\
\hline U6 & Yes & $\begin{array}{l}\min . \\
1836\end{array}$ & 1967 & Water + Tillage & No \\
\hline U7 & No & $?$ & $?$ & Tillage & $?$ \\
\hline U8 & Yes & $\begin{array}{l}\min . \\
1836\end{array}$ & $\begin{array}{l}1837- \\
1944\end{array}$ & Tillage & $?$ \\
\hline U9 & Yes & $\begin{array}{l}\min . \\
1836\end{array}$ & $\begin{array}{l}1946- \\
1958\end{array}$ & Water + Tillage & $?$ \\
\hline U10 & Yes & $\begin{array}{l}\min . \\
1836\end{array}$ & 1967 & Tillage & $?$ \\
\hline U11 & No & $?$ & $?$ & Tillage & $?$ \\
\hline U12 & Yes & $\begin{array}{l}1837- \\
1944\end{array}$ & $\begin{array}{l}1946- \\
1958\end{array}$ & Water + Tillage & $?$ \\
\hline
\end{tabular}

${ }^{\mathrm{a}}$ min. $18 \mathrm{XX}=$ date of the map where the border was mentioned for the first time.

b 18XX-19YY: a date between 18XX and 19YY. 


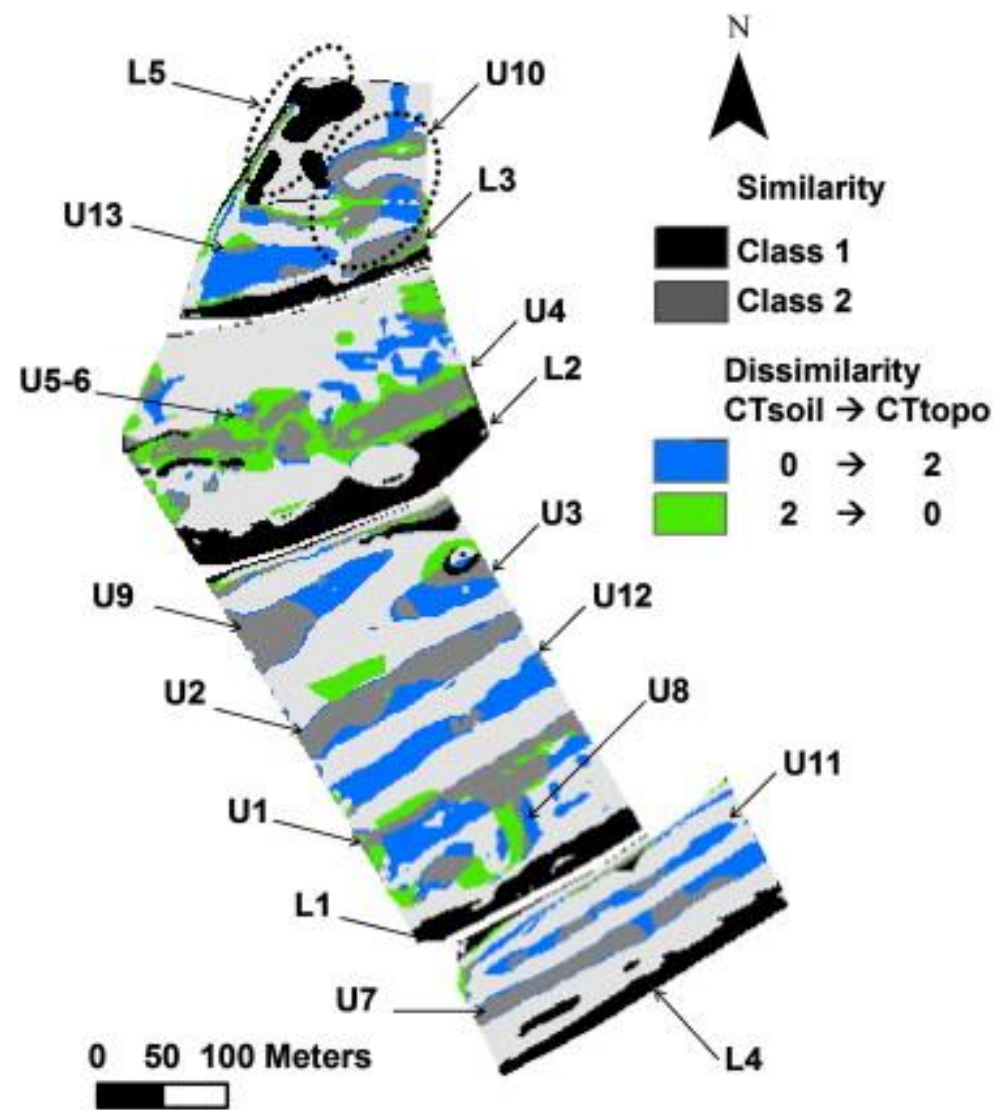

Fig. 11. : Map of similarity/dissimilarity from $\mathrm{CT}_{\text {soil }}$ model against $\mathrm{CT}_{\text {topo }}$ model results. 